\title{
Firms and Credit Constraints along the Value-Added Chain: Processing Trade in China
}

\author{
Kalina Manova \\ Stanford University and NBER \\ Zhihong Yu \\ University of Nottingham
}

\author{
This Draft: November 15, 2012 \\ First Draft: December 15, 2011
}

\begin{abstract}
Global supply chains allow firms in developing countries to share in the gains from trade by conducting either ordinary or processing trade. This paper examines how financial constraints affect companies' choice of trade regime and ultimately profitability. We exploit matched customs and balance sheet data from China, where processing trade is further divided into import-and-assembly (processing firm pays for imported inputs) and pure assembly (processing firm receives imported inputs for free). We establish two main results. First, profits, profitability and value added fall as exporters orient sales from ordinary towards processing trade, and from import-and-assembly towards pure assembly. Second, less financially constrained firms perform more ordinary trade relative to processing trade, and more import-and-assembly relative to pure assembly. We rationalize these patterns with a model that incorporates credit constraints and imperfect contractibility in companies' choice of trade regime. Our results imply that limited access to capital restricts firms to low valueadded stages of the supply chain and precludes them from pursuing more profitable opportunities. Financial frictions thus affect the organization of production across firm and country boundaries, and inform optimal trade policy in the presence of trade in intermediates.
\end{abstract}

JEL Classification codes: F10, F13, F14, F23, F34, G32

Keywords: credit constraints, trade regimes, processing trade, optimal trade policy.

We thank Pol Antràs, Davin Chor and Bob Staiger for insightful conversations, and seminar and conference participants at 2012 International Growth Centre Trade Programme Spring Meeting, 2012 West Coast Trade Workshop, 2012 HBS International Research Conference, 2012 Kiel Institute for World Economy Excellence Award in Global Affairs Workshop, 2012 Stockholm School of Economics Conference on Restructuring China's Economy, CEPII-GEP-Ifo Conference on China and the World Economy, Vanderbilt and Mannheim University for their comments. Kalina Manova acknowledges support from the International Growth Centre (LSE), the Freeman Spogli Institute (Stanford), and the Institute for Research in the Social Sciences (Stanford). Kalina Manova (corresponding author): manova@stanford.edu, Department of Economics, Stanford University, 579 Serra Mall, Stanford, CA 94305. Zhihong Yu: zhihong.yu@nottingham.ac.uk. 


\section{Introduction}

The rapid decline in transportation costs and trade policy barriers over the last few decades has dramatically increased international trade flows. It has in particular enabled the exchange of not only final consumer goods, but also of intermediate inputs for further processing and assembly. This has in turn contributed to the rise in multinational activity and cross-border linkages. The splicing of global production chains raises a number of questions of first-order importance to policy makers. How should trade policy be designed when different stages of the manufacturing process occur in different countries? What are the aggregate welfare and distributional consequences of such trade flows and policies? How does trade in intermediates affect exchange-rate pass-through and the transmission of supply and demand shocks across nations?

To answer these questions, economists first need to understand the benefits and disadvantages of processing trade and the characteristics of the firms that conduct it. Two aspects of China's trade activity make it particularly well-suited for studying these issues. First, for over 30 years China has exempted materials imported for further processing and re-exporting from import duties. Intended as a means of export promotion, this policy has been quite successful at boosting foreign sales. In 2005, $31.7 \%$ of Chinese exporters pursued processing trade and contributed $54.6 \%$ of total exports, making China a key link in global supply chains. Second, within the processing trade regime, Chinese firms choose between two operating modes. Under pure assembly (PA), the Chinese producer receives foreign inputs at no cost from a trade partner abroad to whom it also sends the final product. Under processing with imports (PI), also known as import-and-assembly, the Chinese firm pays for all imported materials and chooses where to source them from. These two institutional features introduce wedges between the costs and returns associated with ordinary trade (OT), PI and PA.

Using matched customs and balance sheet data on the universe of Chinese exporters, this paper examines why firms select into different trade regimes and how this decision affects their performance. We establish two main results. First, export profitability varies systematically across companies with different trading strategies. In particular, profits, profitability and value added decrease as producers re-orient sales from ordinary towards processing trade, and from import-and-assembly towards pure assembly. Second, exporters' financial health determines their trade regime choice. Less credit constrained firms are more likely to pursue ordinary trade relative to processing exports, and importand-assembly relative to pure assembly. We identify the impact of financial frictions by exploiting the variation in short-term liquidity and leverage across firms in an industry, the variation in financial vulnerability across sectors within firms, and the variation in financial development across Chinese 
regions and export destinations. Our results are not driven by differences in size, productivity or extent of foreign ownership across manufacturers. ${ }^{1}$

To rationalize these results, we develop a stylized model that incorporates credit constraints and imperfect contractibility in companies' export decisions. We let producers choose between three trade regimes with distinct working capital requirements. Up-front expenditures and therefore liquidity needs are highest for ordinary exporters who bear all domestic and foreign input costs, import duties and distribution outlays associated with production and trade. Processing with imports entails lower up-front expenses because it avoids import tariffs and marketing costs. Pure assembly demands the least financial resources as it involves only the payment for domestic materials and labor. Firms thus sort into trade modes based on their access to finance. When working capital requirements exogenously vary across sectors, industries' financial dependence also affects the export decision.

In the model, Chinese firms transact with a foreign buyer who incurs any costs not covered by the Chinese supplier. All expenses represent relationship-specific investments with low liquidation value outside the bilateral arrangement. The two partners thus split revenues according to Nash bargaining that assigns bargaining power based on each party's share of total costs. This generates systematically higher profits for the Chinese producer under ordinary trade relative to processing exports, and under import-and-assembly relative to pure assembly.

Our theoretical and empirical results suggest that financial frictions influence the organization of production across firm and country boundaries. The three trading regimes represent decisions over the integration of different steps of the production process (input sourcing, assembly and production of final goods, and export distribution) under the control of the Chinese exporter. Our findings imply that credit constrained firms, and presumably financially underdeveloped countries as a whole, might be stuck in low value-added stages of the supply chain and unable to pursue more profitable opportunities. Strengthening capital markets might thus be an important prerequisite for moving into higher value-added, more profitable activities. Our back-of-the-envelope calculations indicate that these effects can be sizable. Improving firms' financial health to that of the least constrained firm in our sample would increase aggregate Chinese profits by 5.5 billion RMB (1.3\% of the observed level) and real value added by 15.2 billion RMB ( $0.7 \%)$.

Our analysis also illustrates how liquidity constraints shape the design of international trade contracts. Relative to ordinary trade and processing with imports, pure assembly can be seen as a

\footnotetext{
${ }^{1}$ As Dai et al. (2011), we also find that processing exporters are less productive than ordinary exporters in China. Feenstra and Hanson (2005) and Fernandes and Tang (2012) study the prevalence of foreign ownership across different trade regimes in China.
} 
codified form of trade credit extended by the foreign buyer to the Chinese supplier for the purpose of financing imported materials. Our paper thus adds to previous work on the use of trade credit in crossborder transactions (Antràs and Foley 2011). It also resonates with the effect of financial considerations on multinationals' decision to off-shore intra-firm or at arm's length (Antràs et al. 2009, Manova, Wei and Zhang 2009).

Our conclusions shed light on the gains from trade and the role of trade policy in the context of trade in intermediate goods. First, they imply that facilitating access to imported materials can improve countries' export performance. This is particularly relevant for less advanced economies that rely on trade for growth. It is consistent with evidence that the use of foreign inputs enables manufacturers in developing countries to improve product quality and to broaden product scope, thereby enhancing export activity (Kugler and Verhoogen 2008, 2009, Goldberg et al. 2010, Manova and Zhang 2012). To the extent that multilateral reductions in import tariffs would encourage trade in both intermediate and final goods between trade partners, global production chains also point to complementarities in trade policy across countries (Antràs and Staiger 2011).

Second, our findings highlight the differential effects of trade policy across heterogeneous firms. Specifically, more liquidity constrained manufacturers might benefit more from import liberalization. The processing regime in China potentially allows producers that would have otherwise been unable to pursue any cross-border operations to share in the gains from trade. Imperfect financial markets might thus provide some justification for government intervention in the regulation of international trade flows. An important caveat to this conclusion is that we have not examined the effect of the processing regime on firms in import-competing sectors. The latter could be limited, however, if most imported materials cannot be manufactured locally in practice.

More broadly, our analysis contributes to two recent literatures. It speaks to the growing evidence that credit constraints impede firms' export activity and distort aggregate trade flows, both in normal times and during crisis episodes (Manova 2007, Berman and Héricourt 2008, Bricongne et al. 2010, Amiti and Weinstein 2011, Minetti and Zhu 2011, Chor and Manova 2012). Our contribution is in identifying a novel mechanism - choice of trade regime - through which liquidity constraints impact firms' export outcomes and ultimately profitability. There has also been increased interest in the structure of global supply lines and their implications for the transmission of shocks across countries during the recent financial crisis (Johnson 2011, Bems et al. 2011, Levchenko et al. 2010). ${ }^{2}$ To this

\footnotetext{
${ }^{2}$ Kim and Shin (2012) model global supply chains with production delays and show that inventories, accounts receivable and productivity are procyclical and track financial conditions.
} 
line of research we add a better understanding of how and why firms operate at different stages along the value added chain.

The remainder of the paper is organized as follows. We provide institutional background on China's trade regimes in the next section. After developing a stylized theoretical framework in Section 3, we introduce the data in Section 4 and present the empirical results in Section 5. We quantify the aggregate distortion due to credit constraints in Section 6. The last section concludes.

\section{Institutional Background}

For the past 30 years, China has used a variety of trade policy instruments to stimulate export activity. A particularly consequential intervention has been the exemption of imported inputs for further processing and re-exporting from import duties. In place since the mid-1980s, this provision substantially reduces the cost of sourcing intermediate goods from abroad. This benefits exporters already using foreign inputs for processing trade and encourages more firms to engage in the global value chain. It also incentivizes more overseas companies to move parts of their production process to China via arms-length contracts or owned-and-operated subsidiaries. Finally, it can allow Chinese entrepreneurs to manufacture new products requiring materials that are not available domestically. Similarly, Chinese firms might be able to upgrade product quality by importing inputs of higher quality than locally attainable, and to thereby become more competitive in foreign markets.

The Chinese customs authorities distinguish between two key regimes: processing trade and ordinary trade. ${ }^{3}$ Processing trade is officially defined as "business activities in which the operating enterprise imports all or part of the raw or ancillary materials, spare parts, components, and packaging materials, and re-exports finished products after processing or assembling these materials/parts". ${ }^{4} \mathrm{~A}$ processing firm can claim import duty exemption only if, at the time of importing, it shows proof of a contractual agreement with a foreign buyer to whom it will export the processed goods.

The processing trade regime comprises two very different sub-categories: import-and-assembly and pure assembly. The latter is also known as processing with foreign client-supplied materials. It refers to "business activities in which the operating enterprise receives materials/parts from a foreign enterprise without needing to pay foreign exchange for the import, and carries out processing or assembling with the materials/parts as per the requirements of the foreign enterprise, only charging for

\footnotetext{
${ }^{3}$ There are a number of other trade regimes that capture less than $4 \%$ of total exports. These include capital goods and equipment for foreign-invested enterprises, capital goods for the production of processed exports, border trade, compensation trade, transactions by international organizations, etc.

${ }^{4}$ The trade regime definitions in this section come from "Measures of the Customs of the People's Republic of China on the Control of Processing-Trade Goods" released in 2004 and amended in 2008 and 2010.
} 
the processing or assembling, while any finished products are to be sold and marketed by the foreign enterprise." By contrast, import-and-assembly, also known as processing with imported materials, refers to "business activities in which the operating enterprise imports materials/parts by paying foreign exchange for their processing, and exports finished processed products for sale abroad".

In other words, under both types of processing trade, the import duty is waived, the Chinese party pays for all domestic manufactured inputs and labor, and the foreign buyer is responsible for the marketing and distribution of the final product abroad. However, under pure assembly, the Chinese firm does not participate in identifying appropriate foreign materials and incurs no cost for using them. By contrast, under import-and-assembly, the Chinese firm decides what intermediates to source from which countries and at what prices. It retains full control over these decisions and has to pay foreign suppliers for any imported inputs. This foreign input supplier will typically not be the party to whom the Chinese firm ultimately exports. Whichever trade partner secures a given input also preserves ownership rights over it.

Ordinary Chinese imports incur regular import duties and are not subject to any exemptions. They include final goods purchased from abroad for sale in China, as well as foreign materials used in production for the domestic market. Ordinary exports are often manufactured exclusively with local inputs. However, firms can import intermediates, combine them with domestic parts, and then sell both in China and abroad. This makes it prohibitively difficult for the Chinese Customs to ascertain what fraction of the imported goods by value will eventually be used towards production for exporting at the time of importing. This is especially true of Chinese firms exporting under their own brand. Conversely, if a Chinese manufacturer (such as a garment-maker) uses imported materials in order to sell domestically under its own brand (e.g. Youngor) and to export abroad under a foreign brand (e.g. Nike, Gap), its imports would be recorded separately and it would enjoy the tax waiver on the processing imports but not on the foreign inputs used for domestic production.

Compared to processing firms, ordinary exporters therefore face higher up-front production costs because they have to pay for any foreign inputs at a surcharge. They also bear full responsibility for the costs of identifying input suppliers and of distribution to final buyers abroad.

The creation of the processing trade regime has significantly contributed to the expansion of China's trade activity. In 2005, for example, $54.6 \%$ of all exports represented processing trade. While China's import duties have declined substantially over time, the exemption for processing imports remains important: Average tariff rates dropped from 41\% in 1992 to $16.8 \%$ before entry into the WTO in 2001 and reached 9\% in 2005 (Lemoine and Ünal-Kesenci 2004, Yu 2011). 


\section{Theoretical Framework}

We develop a stylized model of firms' export choices in the presence of the three trade regimes described above. Our main interest is in highlighting how limited access to external finance affects operation decisions, export outcomes and ultimately firm profitability. We thus intentionally abstract away from many complicating and economically relevant factors, in order to quickly illustrate the main mechanisms and intuitions at play. We then discuss how incorporating a number of more realistic features into the model would modify and amplify its empirical predictions. We have refrained from introducing these in our baseline approach since our data does not allow us to test them directly.

The model is in partial equilibrium and from the perspective of a Chinese firm deciding what export activity to undertake. It implicitly assumes that there is sufficient demand abroad both for goods

supplied by ordinary Chinese exporters, as well as for outsourcing production to China via processing trade. In other words, for any trade regime chosen by the Chinese firm, there will be a foreign buyer willing to enter the partnership. We believe this approximates well the economic environment in China and allows us to concentrate specifically on the trade-offs faced by the Chinese entrepreneur.

\section{$3.1 \quad$ Set up}

Consider a manufacturer $(M)$ producing for a foreign market. Export demand is fixed and normalized to 1 , such that potential revenues are $R$. Production requires the use of domestic intermediate inputs and labor worth $C_{D}$ and foreign materials worth $C_{F}$. Servicing consumers abroad entails an additional outlay $F$ for marketing and managing a distribution network. $M$ chooses to operate under one of three possible trade regimes: ordinary trade $(O T)$, import-and-assembly ( $P I$, for processing with imports), and pure assembly $(P A)$. When foreign materials are imported under processing trade $(P A$ or $P I)$, they do not incur any customs duties. Foreign parts sourced under ordinary trade face an ad-valorem tariff $\tau$ at the time of import since border agents cannot ensure that the inputs will be processed and reexported. For expositional simplicity, our baseline model assumes that this tax is rebated at the time the final product is shipped abroad. Section 3.6 discusses the consequences of relaxing this assumption. All relevant characteristics of the three trade regimes are summarized in Table 1.

\subsection{Firm costs}

The manufacturer's choice over trade regimes determines how the costs associated with the export transaction are shared between $M$ and any foreign party. While ex-post total expenses are always $C_{D}+C_{F}+F$ after any tariff rebates, $M$ 's ex-ante expenses depend on the trade mode. 
Under pure assembly, $M$ establishes a contractual relationship with a buyer $(B)$ overseas who commits to provide all foreign inputs at no charge to $M$ and is responsible for marketing and distribution abroad. Since the transfer of foreign materials occurs under processing trade, it avoids import duties. The up-front costs to $M$ and $B$ are therefore $T C_{P A}=C_{D}$ and $C_{F}+F$ respectively.

Under import-and-assembly, $M$ enters an agreement with a foreign buyer who manages the sale of the product to consumers abroad. The manufacturer retains control over the sourcing of all production inputs and is in charge of any associated expenses. No import duties are imposed on foreign intermediates as they enter the country under the processing regime. The up-front costs to $M$ and $B$ are thus $T C_{P I}=C_{D}+C_{F}$ and $F$ respectively.

Under ordinary trade, $M$ operates completely independently and handles all aspects of the cross-border sale. The firm secures all domestic and foreign inputs, and organizes its distribution network in the destination market. It transacts directly with final consumers abroad who bear no costs. ${ }^{5}$ Imported parts are taxed at the time of purchase, but these duties are refunded when the transaction is complete. The up-front costs to $M$ and $B$ are now $T C_{O T}=C_{D}+(1+\tau) C_{F}+F$ and 0 .

\subsection{Firm profits}

Contracts are imperfectly enforced and this exposes firms to the risk of hold-up problems once costs have been incurred. Should the relationship break-up, both parties are able to recoup their costs, $M$ by selling the final product to another buyer at marginal cost and $B$ by offering its distribution services to another supplier at a price equal to its expenses. ${ }^{6}$ Trade partners therefore negotiate over the surplus from the relationship, $R-C_{D^{-}} C_{F}-F$. In particular, the two parties engage in Nash bargaining with bargaining weights corresponding to their relative contribution to the relationship. To fix ideas, we assume these weights reflect the share of costs borne by a party.

Denoting the manufacturer's bargaining weight as $\beta_{i}=\frac{T C_{i}}{C_{D}+C_{F}+F}$, his profits under trade regime $i$ are therefore given by:

$$
\begin{gathered}
\pi_{i}=-T C_{i}+T C_{i}+\beta_{i}\left(R-C_{D}-C_{F}-F\right)=\beta_{i}\left(R-C_{D}-C_{F}-F\right), \quad i \in\{P A, P I, O T\} \\
\text { where } \beta_{P A}=\frac{C_{D}}{C_{D}+C_{F}+F}<\beta_{P I}=\frac{C_{D}+C_{F}}{C_{D}+C_{F}+F}<\beta_{O T}=\frac{C_{D}+C_{F}+F}{C_{D}+C_{F}+F}=1 .
\end{gathered}
$$

\footnotetext{
${ }^{5}$ Our results will be qualitatively unchanged if the firm sold to a foreign retailer who is responsible for some of the distribution costs. All that is required in that case is that those costs are incurred after the exporter has been paid. The cost $F$ to the manufacturer can then be interpreted as the cost of searching and matching with this foreign retailer, which is not required under processing trade.

${ }^{6}$ Assuming that parties' outside option is a fraction of the cost they incurred would not affect our results qualitatively.
} 


\subsection{Credit constraints and trade regime choice}

All costs associated with exporting are incurred up-front, before production takes place. All revenues and payoffs are, however, realized after trade has occurred. For simplicity, we assume that the foreign buyer does not face any liquidity needs and can cover his outlays with cash flows from operations or outside capital. The manufacturer, on the other hand, is unable to retain earnings from one period to the next because all profits have to be paid out as dividends to stockholders (for example due to moral hazard issues). Thus, whether $M$ can engage in any trade activity and if so, under what organizational mode, depends on $M$ 's ability to raise external funding for his expenses. Let $M$ have access to bank loans in the amount $L$, which can vary across firms within a sector, as well as across sectors.

In the very stylized set-up we consider, there is a clear ranking of $M$ 's export profits $(\pi)$ and total up-front costs $(T C)$ across trade regimes: both are lowest with pure assembly, higher with importand-assembly, and highest with ordinary trade.

$$
\begin{array}{ll}
\text { Profits: } & \pi_{P A}<\pi_{P I}<\pi_{O T} \\
\text { Liquidity needs: } & T C_{P A}<T C_{P I}<T C_{O T}
\end{array}
$$

Ordinary trade would therefore be the dominant export strategy in the absence of credit constraints. With financial frictions, however, the manufacturer will pursue the most profitable trade regime he can given his available external capital $L$.

Proposition 1 Most financially constrained exporters $\left(C_{D} \leq L<C_{D}+C_{F}\right)$ conduct pure assembly and earn low profits. Less financially constrained exporters $\left(C_{D}+C_{F} \leq L<C_{D}+(1+\tau) C_{F}+F\right)$ conduct import-and-assembly and earn higher profits. Least financially constrained exporters $\left(L \geq C_{D}+(1+\right.$ $\left.\tau) C_{F}+F\right)$ conduct ordinary trade and earn the highest profits.

\subsection{Mixed export strategies}

Proposition 1 has the stark implication that each firm manufactures one particular product and chooses a unique trade mode. If the producer makes multiple goods in one or more sectors, and if these goods have different cost and revenue structures, it can be optimal for the firm to export some merchandise via processing trade and some via ordinary trade. This decision will depend on the seller's total access to capital. Firms will allocate their limited financial resources to different product lines so as to maximize total profits. The most advantageous allocation will balance the trade-off companies face between expanding product scope and pursuing higher-return transactions: On the one hand, processing trade (especially pure assembly) uses up less liquidity per product line than ordinary trade 
and thereby allows the firm to manufacture more goods. This tends to increase the extensive margin of firm revenues. On the other hand, processing exports (especially pure assembly) generate lower profit margins. This tends to decrease the intensive margin of firm revenues.

While this profit-maximizing problem is complex, its solution is rather intuitive. Manufacturers will optimally choose ordinary trade for products with relatively low up-front costs and high revenue potential. By contrast, they will opt for processing with imports for goods with intermediate cost and revenue levels. Firms will finally settle for pure assembly for articles with high liquidity requirements but limited returns. It can thus be optimal for multi-product firms to adopt mixed export strategies. This suggests systematic variation in companies' proclivity to use different trade regimes across sectors.

Proposition 2 Across sectors within a firm, the share of processing exports in total exports $\left(\frac{X_{P A}+X_{P I}}{X_{P A}+X_{P I}+X_{O T}}\right)$ and the share of pure assembly in processing exports $\left(\frac{X_{P A}}{X_{P A}+X_{P I}}\right)$ increase with sectors ${ }^{\prime}$ liquidity needs.

Note that exporters with more access to finance will differ from capital-scarce firms in two respects. For any given product or sector, less constrained manufacturers will be more likely to select into ordinary trade relative to processing trade, and into import-and-assembly relative to pure assembly (as per Proposition 1). In addition, financially healthier producers may be able to trade in more goods, especially in sectors with higher liquidity needs. Aggregating to the firm level, this implies a "smoothed" version of Proposition 1.

Proposition 3 Across firms, the share of processing exports in total exports $\left(\frac{X_{P A}+X_{P I}}{X_{P A}+X_{P I}+X_{O T}}\right)$ and the share of pure assembly in processing exports $\left(\frac{X_{P A}}{X_{P A}+X_{P I}}\right)$ increase with firms' liquidity constraint. Across firms, profits fall with both shares, $\frac{X_{P A}+X_{P I}}{X_{P A}+X_{P I}+X_{O T}}$ and $\frac{X_{P A}}{X_{P A}+X_{P I}}$.

\subsection{Discussion}

Although the stylized framework above rests on a number of simplifying assumptions, we believe the main predictions it delivers would be robust to a wide range of alternative set-ups. Here we discuss a few potential extensions that would retain our central results in richer environments. 


\section{Endogenous inputs and outputs}

We have so far restricted firms to producing fixed output levels with fixed input supplies and implicitly ruled out moral hazard. However, if parties actively choose the quantity or quality of input materials and exert effort in production, output levels and revenues would be endogenous to the trade regime choice. This would arise because of a standard agency problem from the theory of the firm (Grossman and Hart 1986, Hart and Moore 1990): While parties incur the full cost of a given input, they receive only a share of its marginal revenue due to imperfect contractibility and Nash bargaining. This leads to underinvestment and suboptimal output levels.

Moral hazard could play out in a number of ways in the context we consider. In all three trade regimes, the Chinese producer might need to exert effort in locating domestic materials and hiring local labor that are both well suited to the manufacturing process and at an attractive price. The same could be true of sourcing foreign parts under ordinary exports and processing with imports (but not with pure assembly when the trade party presumably does so). $M$ might also exert effort in managing plant operations and converting inputs into a final product. The higher his bargaining weight, the more effort he would have the incentive to put in and the higher sales would presumably be. This would preserve the ranking of trade regimes but magnify the difference in revenues across them. Moral hazard can thus accentuate the negative impact of liquidity constraints on firms' profitability.

\section{Ordinary trade without foreign inputs}

Our baseline model assumes that ordinary exporters use domestic and foreign inputs in the same proportion as processing firms. Companies selling abroad under ordinary trade, however, may choose to use only domestic intermediates or fewer imported parts. If local materials are cheaper, this strategy could reduce up-front production costs, especially in the absence of a tariff rebate (see below). Pure assembly would remain the trade mode with the lowest liquidity requirements, but the relative ranking of total costs under ordinary exports and processing with imports would become theoretically ambiguous. It would be preserved provided that the distribution $\operatorname{cost} F$ is sufficiently large, foreign inputs sufficiently important for production, and/or Chinese materials not too cheap.

If sales are not influenced by the switch towards domestic parts, ordinary trade could become even more profitable relative to both processing modes. Output quality and revenues might suffer, however, if local materials are inferior to imported components and make the product less appealing to foreign consumers. This could make the profitability ranking of ordinary vs. processing trade ambiguous (though that of PA and PI would be preserved). Such reversals would be less likely than in the sorting by financial needs, though, because of the differences in bargaining weights across regimes. 
Moreover, when manufacturers' effort responds to incentives as discussed above, ordinary exporters would invest the most of all three types in identifying complimentary inputs and marketing the product. This would serve to improve firm profitability.

Ultimately, theoretical ambiguities indicate that which mechanism dominates is an empirical matter and could work against us in the empirical analysis.

\section{No tariff rebate}

In reality, ordinary exporters cannot claim refunds on the duties they pay to import inputs. This increases their total costs and reduces expected profits. Once again, firms' sorting into the two types of processing trade would be unaffected. The relative position of the ordinary trade regime in terms of working capital needs also remains the same. The ordering of its profitability could, however, be overturned if import tariffs are sufficiently large. Given that they averaged 9\% in 2005 (the year in our data), as well as the discussion of endogenous input choices above, this does not appear very likely.

\section{Productivity Heterogeneity}

Our stylized framework has abstracted away from heterogeneity across firms along dimensions other than liquidity constraints. It is well established in the literature, however, that productivity is an important determinant of export outcomes. To the extent that productivity and access to finance are imperfectly correlated, both factors would likely matter for firms' trade regime choices in a richer model. For example, each of the three expenses considered $\left(C_{D}, C_{F}\right.$, and $\left.F\right)$ plausibly has a fixed-cost and a variable-cost component. In the spirit of Melitz (2003), this could imply that most productive manufacturers self select into ordinary trade, less productive companies pursue processing with imports, and least productive exporters undertake pure assembly. Some very inefficient enterprises might be unable to engage in any form of cross-border activity.

The literature has also argued that more productive exporters are endogenously less credit constrained because their expected revenues are higher and they can therefore provide stronger incentives to financiers to fund their operations (Manova 2012). This mechanism would suggest that conditioning on firm productivity should leave no additional explanatory power for firms' financial health per se. We explore the relative importance of productivity and access to capital for exporters' trade regime choices in Section 5.2.

\section{Endogenous credit constraints}

Finally, we discuss the possibility that firms' access to internal and external capital might be endogenous to their choice of trade regime. First, banks might be more willing to fund firms with 
higher expected profits. This would reinforce the predictions of the model because the more profitable export modes are also the ones with lower liquidity needs. We return to this point in Section 5.4.

Second, entrepreneurs might be able to retain earnings from one period to the next. Over time, it might thus be possible for firms that begin with processing trade to accumulate sufficient financial resources and later move into ordinary trade. While these transitions could have important policy implications for aggregate growth, the cross-sectional predictions of the model that we take to the data would be unaffected.

Finally, exporters might be able to secure trade credit from the foreign buyers. Evidence by Antràs and Foley (2011) suggests that such trade-credit relationships develop over time as they rest on trust and reputation effects. In some sense, the buyer's willingness to provide foreign inputs free of charge under pure assembly is a manifestation of trade credit. To the extent that firms exporting under ordinary trade or processing with imports are able to obtain trade credit as well, their liquidity constraints would be relaxed and our results biased downwards.

\section{Data}

\subsection{Trade and balance-sheet data}

Our analysis makes use of two recently released proprietary datasets on the activities of Chinese firms in 2005. The first one comes from the Chinese Customs Office and contains detailed information about the universe of trade transactions. ${ }^{7}$ It reports the value of firm exports (free on board) and imports (cost, insurance and freight included) in U.S. dollars by product and trade partner for 243 destination/source countries and 7,526 different products in the 8-digit Harmonized System. ${ }^{8}$ The records also indicate whether each cross-border operation occurs under ordinary trade, processing with imports or pure assembly. This allows us to construct indicators of the proclivity for using different trade regimes at the firm- or firm-sector level.

The second database we employ is the Annual Surveys of Industrial Firms (ASIF) conducted by China's National Bureau of Statistics. It provides standard balance sheet data for all state-owned enterprises (SOEs) and all private companies with sales above 5 million Chinese Yuan ${ }^{9}$. The main variables of interest to us are measures of firm profitability and access to finance, which we discuss in greater detail below. We also use information on employment, capital and material inputs to construct

\footnotetext{
${ }^{7}$ Manova and Zhang (2008) describe the data and stylized facts about firm heterogeneity in Chinese trade.

${ }^{8}$ Product classification is consistent across countries at the 6-digit HS level. The number of distinct product codes in the Chinese 8-digit HS classification is comparable to that in the 10-digit HS trade data for the U.S..

${ }^{9}$ This is equivalent to 0.6 million USD based on the USD-CNY exchange rate in 2005.
} 
proxies for firm size and productivity. Firms are legally required to complete both the census and the customs declaration forms, and compliance is strictly enforced by different government agencies. ${ }^{10}$

Our empirical analysis critically relies on combining data from both sources. While each is organized around company registration numbers, the authorities have not released a unique firm identifier. We therefore merge the census files to the customs records based on an algorithm that matches firms' names and key contact information, including addresses and phone numbers. ${ }^{11}$ While imperfect, this procedure generates a large and representative sample. We are able to obtain balance sheet data for $30 \%$ of all exporters in the customs registry, and trade data for $67 \%$ of all producers in the census that report positive export activity. As Table 2 shows, the matched exporters have similar trade patterns to the unmatched ones. Likewise, the balance sheets of the matched firms from the census are comparable to those of the unmatched.

Some Chinese corporations (mostly SOEs) are pure export-import companies that do not engage in manufacturing but serve exclusively as intermediaries between domestic producers (buyers) and foreign buyers (suppliers). Following standard practice in the literature, we identify such wholesalers using keywords in firms' names and exclude them from our sample. ${ }^{12} \mathrm{We}$ do so in order to focus on the operations of firms that both make and trade goods since we are interested in how access to finance affects their export decisions. Trading enterprises face very different choices and financing needs, whose study we leave to future work.

Table 2 illustrates the substantial variation in performance and trade activity across the 50,606 Chinese firms in our matched sample. (Log) profits and (log) value added average 7.33 and 9.23, with a standard deviation of 1.95 and 1.48 , respectively. The dispersion in profitability, measured by the ratio of profits to sales, is even greater with a mean of 0.03 and standard deviation of 0.20 .

Our analysis examines two indicators of firms' choice over trade regimes. The first represents the share of processing exports (both pure assembly and import-and-assembly) in total exports and is labeled $(\mathrm{PA}+\mathrm{PI}) /(\mathrm{PA}+\mathrm{PI}+\mathrm{OT})$. The second distinguishes between the two processing modes and gives the share of pure assembly in total processing exports, $\mathrm{PA} /(\mathrm{PA}+\mathrm{PI})$. In Table 2, both of these ratios have been constructed based on aggregated firm sales across all destinations and product categories. As evident from the summary statistics, the trade-regime composition of export activity

\footnotetext{
10 As in Wang and $\mathrm{Yu}$ (2011), the NBS data are cleaned by excluding observations according to the following criteria: (a) firms in non-manufacturing industries (2-digit GB/T industry code $>43$ or $<13$ ) and tobacco (GB/T code 16); (b) observations with negative values for output, sales, exports, capital, or intermediate inputs; (c) observations with total assets less than total fixed assets or total liquid assets, or with total sales less than exports.

${ }^{11}$ See Wang and $\mathrm{Yu}$ (2011) for a detailed description of the matching procedure.

${ }^{12}$ We drop 29,982 wholesalers who mediate $22.3 \%$ of China's trade. Using the same data, Ahn et al. (2011) identify intermediaries in the same way in order to study wholesale activity.
} 
varies significantly across firms in the sample. In some specifications below, we further explore the variation across countries and industries within exporters and calculate these shares for each firmdestination pair, firm-sector pair, or firm-sector-destination triplet.

While many Chinese producers operate in one unique trade mode, a sizable group transact under multiple regimes. The Venn diagram in Figure 1 shows the percentage share of firms engaged in each of 7 possible combinations of export methods (PA; PI; OT; PA and PI; PA and OT; PI and OT; PA, PI and OT). The reported percentages sum to $100 \%$. $63.0 \%$ of all sellers ship only ordinary exports, while $2.7 \%$ and $11.0 \%$ conduct exclusively pure assembly and processing with imports, respectively. The remaining $23.3 \%$ pursue mixed trade strategies, with $3.5 \%$ of all exporters undertaking some activity under all three regimes. Similar patterns obtain when we look at a finer level of disaggregation and consider firm-sector pairs instead of firms (not reported). Figure 2 replicates Figure 1, but instead of showing the percentage share of firms in a segment, it reports the percentage share of total exports captured by firms in that segment. It is evident that processing trade, especially PI, contributes substantially more to the value of Chinese exports than its number of firms would suggest. This is despite the low value added associated with processing trade (see below) and is primarily because of its high import content.

Given that manufacturers use different modes of servicing export markets, it is not surprising that they also source foreign materials in different ways. Moreover, companies exporting under more than one trade regime acquire intermediates under multiple regimes as well. Figure $3 \mathrm{~A}$ summarizes the use of imported inputs by firms reporting any ordinary exports (left bar) and firms reporting any processing exports (right bar). Ordinary exporters are significantly less likely to use foreign parts. Conditional on importing materials, they are more likely to do so under ordinary trade. These patterns are even more extreme when we focus on suppliers engaged exclusively in either ordinary or processing exports but not both (Figure 3B).

\subsection{Measuring credit constraints}

We use balance sheet data to construct two main measures of firms' financial health that are standard in the literature. ${ }^{13}$ Liquidity gives the difference between current assets and current liabilities, scaled by total assets. It captures firms' availability of liquid capital. Leverage reflects the ratio of short-term debt to current assets. Higher leverage indicates that firms have more financial obligations in the short

${ }^{13}$ See for example Whited (1992), Fazzari and Petersen (1993), Greenaway et al. (2007), and Ding et al. (forthcoming). Our liquidity variable is consistent with the definition of liquidity constraint in our theoretical model. 
run, less freedom in managing their cash-flows, and greater difficulty in raising additional funds. We thus expect exporters with high liquidity and low leverage to be less constrained.

We also employ four different proxies for sectors' financial vulnerability, which have been commonly used in the literature on the role of credit constraints for trade and growth. ${ }^{14}$ These variables are meant to reflect technologically-determined characteristics of each sector that are inherent to the nature of the manufacturing process and beyond the control of individual firms.

There are systematic differences across sectors in the relative importance of up-front costs and the lag between the time when production expenses are incurred and the time when revenues are realized. We capture these differences with the ratio of inventories to sales $\left(\right.$ Invent $\left._{i}\right)$. It proxies the duration of the manufacturing process and the working capital firms need in order to maintain inventories and meet demand. For robustness, we also use sectors' external finance dependence $\left(\operatorname{ExtFin}_{i}\right)$, constructed as the share of capital expenditures not financed with internal cash flows from operations. We further exploit the share of $\mathrm{R} \& \mathrm{D}$ spending in total sales $\left(R D_{i}\right)$, since research and development typically occur at the beginning of a production cycle before a good can be manufactured and successfully marketed. Note that $\operatorname{ExtFin}_{i}$ and $R D_{i}$ primarily reveal firms' long-term requirements for outside capital and thus reflect in large part fixed costs. Invent, on the other hand, indexes producers' liquidity needs in the short run, which are associated mainly with variable costs including the cost of intermediate inputs.

Sectors vary not only in firms' reliance on external finance, but also in firms' endowment of hard assets that can serve as collateral. We thus also use a measure of asset tangibility $\left(\right.$ Tang $\left._{i}\right)$, defined as the share of net plant, property and equipment in total book-value assets.

As is standard in the literature, these sector measures are constructed from data on all publicly traded U.S.-based companies from Compustat's annual industrial files. This approach is motivated by a number of considerations. First, the United States have one of the most advanced and sophisticated financial systems, which makes it reasonable that the behavior of U.S. companies reflects firms' optimal asset structure and use of external capital. Second, using the U.S. as the reference country eliminates the potential for the measure of sectors' financial vulnerability to endogenously respond to China's level of financial development. In fact, if the most financially vulnerable industries in the U.S. employ more internal financing and tangible assets in China because of the worse financial system there, our results would be biased downwards. Finally, what is required for identification in the

\footnotetext{
${ }^{14}$ These sector measures come from Kroszner, Laeven and Klingebiel (2007), and are constructed following the methodology of Rajan and Zingales (1998) and Claessens and Laeven (2003). They are averaged over the 1980-1999 period for the median U.S. firm in each sector, and appear very stable over time.
} 
empirical analysis is not that industries have the same tangibility and liquidity needs in the U.S. and China, but rather that the ranking of sectors remain relatively stable across countries. Kroszner, Laeven and Klingebiel (2007), Rajan and Zingales (1998) and Claessens and Laeven (2003), among others, argue that the measures of financial vulnerability capture a large technological component that is innate to a sector and therefore a good proxy for ranking industries in all countries. Consistent with this argument, the measures vary substantially more across industries than across firms within an industry, and the hierarchy of sectors is quite stable over time.

The four indicators of financial vulnerability are available for 29 sectors in the ISIC 3-digit classification system. In our empirical analysis, we match Chinese HS 8-digit product codes to these ISIC 3-digit sector categories.

A first glimpse at the variation in trade activity with firms' financial health and sectors' financial vulnerability reveals patterns consistent with the predictions of the model. In Figure 4A, we divide firms into two subsamples with liquidity above or below the sample median. ${ }^{15}$ While the average share of processing trade in total exports is $29.4 \%$ for high-liquidity firms, it is $31.2 \%$ for lowliquidity firms. The corresponding numbers are $17.7 \%$ and $19.4 \%$ for the share of pure assembly in processing exports. When we distinguish between sectors with working capital requirements above and below the sample median, we obtain substantially bigger differences in trade patterns. In industries with high inventory-to-sales ratios, the typical firm conducts $19.9 \%$ of its exports via processing trade and $22.7 \%$ of its processing exports via pure assembly. By contrast, these shares drop to $14.3 \%$ and $14.6 \%$ for industries with low inventory-to-sales ratio.

\section{Empirical Results}

The empirical analysis proceeds in three steps. We first document the relationship between exporters' profitability and type of trade regime. We then establish the causal effect of financial constraints on companies' choice of export mode. Finally, we provide additional support for our interpretation by showing that this effect is stronger in circumstances when we expect it to be stronger and by studying firms' use of imported inputs.

\subsection{Trade regimes and firm profitability}

We first study the association between firm performance and trading modes. According to Proposition 3 , profitability should increase monotonically as exporters re-orient foreign sales from pure assembly

\footnotetext{
${ }^{15} \mathrm{We}$ control for systematic differences in liquidity across firms with different ownership structures by defining these medians separately for private domestic firms, state-owned enterprises, joint ventures and foreign affiliates.
} 
to processing with imports to ordinary trade. We therefore consider two indicators of the composition of companies' shipments abroad: the share of processing exports in total exports $\left(\frac{X_{P A}+X_{P I}}{X_{P A}+X_{P I}+X_{O T}}\right)$ and the share of pure assembly in processing exports $\left(\frac{X_{P A}}{X_{P A}+X_{P I}}\right)$. We construct these trade shares at the firm level, after summing exports across all destinations serviced and products sold. ${ }^{16}$ For each ratio, we estimate the following specifications in the matched sample of exporters with balance-sheet data:

$$
\text { Performance }_{f}=\alpha+\beta \cdot \text { Trade Share }_{f}+\gamma \cdot \log \text { Empl }_{f}+\varphi_{p}+\varphi_{i}+\varphi_{\text {own }}+\varepsilon_{f}
$$

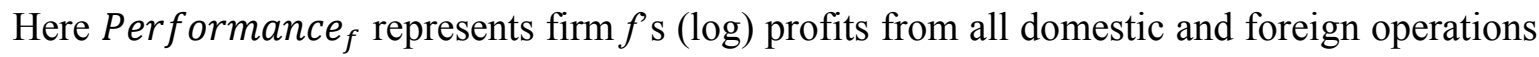
or $f$ 's profitability, i.e. its profits-to-sales ratio. The census records producers' location in China and the main sector in which they operate. This allows us to use province $\varphi_{p}$ and industry $\varphi_{i}$ fixed effects in order to account for systematic differences across 31 regions and 738 sectors (4-digit GBT codes) that might affect all manufacturers. These capture differences in factor costs, factor intensities, transportation costs, financial market development, institutional frictions, tax treatment, etc. that might favor one export mode over another and directly impact profitability. We additionally control for firm size, as proxied by (log) employment. Finally, we condition on the ownership status of the firm since foreign corporations might have distinct incentives and attributes compared to local companies. In particular, we include dummies for state-owned enterprises, joint ventures and wholly-owned multinational affiliates, the excluded category being private domestic firms. We employ Huber-White heteroskedasticity robust standard errors $\varepsilon_{f}$.

We are primarily interested in $\beta$, which reflects (the sign of) the conditional correlation between firms' profitability and choice of trade regime. This coefficient is identified purely from the variation across exporters within narrowly defined segments of the economy. We emphasize that we cannot and do not want to give $\beta$ a causal interpretation since producers' profits and export activity are both affected by firms' financial health in our model and are the joint outcome of firms' maximization problem. In practice, other firm attributes ignored by our theoretical framework might also influence both variables.

The results in Columns 1 and 2 of Table 3 strongly suggest that profitability indeed varies systematically with firms' trade regime in a way consistent with the model. Manufacturers' profits and profitability increase with the share of processing exports in total foreign sales (Panel A) and with the

\footnotetext{
${ }^{16}$ In unreported results available on request, we have performed the entire empirical analysis and obtained consistent results for the $\frac{X_{P A}}{X_{P A}+X_{O T}}$ and $\frac{X_{P I}}{X_{P I}+X_{O T}}$ ratios as well.
} 
share of pure assembly in processing trade (Panel B). These patterns are independent of the fact that bigger firms (as proxied by the size of the labor force) tend to be more profitable. They are also economically significant. A $10 \%$ shift in export activity from processing towards ordinary trade is associated with $1.5 \%$ higher profits. Re-allocating $10 \%$ of foreign processing sales from pureassembly to import-and-assembly is accompanied by a $2.8 \%$ rise in profits. A one-standard-deviation increase in the two trade shares corresponds to $6.5 \%$ and $10.7 \%$ more profits.

As standard with balance sheet data, Chinese firms do not report profits separately for domestic and foreign sales. To the extent that trade regime choices affect revenues abroad but not operations at home, the results in Columns 1-2 likely underestimate the importance of the trade mode for export profitability. To shed light on this, in Columns 4-5 we focus on firms that sell exclusively in foreign markets but not domestically. While these "pure exporters" represent only about $20 \%$ of our matched sample, we can be sure that their profits capture only cross-border activities. As anticipated, we indeed obtain higher point estimates in this group of producers.

Note that the total value added in the manufacturing process does not depend on firms' export regime in our stylized set-up. It is instead equal to the surplus from the bilateral partnership and given by $R-C_{D}-C_{F}-F$. As discussed in Section 3.6, however, value added might vary systematically across trading modes if input and output choices are endogenous and parties exert effort proportionately to their bargaining power in the sharing of revenues. The evidence in Column 3 and 6 of Table 3 lends support to this conjecture. We find that a higher share of processing exports, and of pure assembly in particular, are associated with substantially lower levels of value added. Raising $\frac{X_{P A}+X_{P I}}{X_{P A}+X_{P I}+X_{O T}}$ and $\frac{X_{P A}}{X_{P A}+X_{P I}}$ by one standard deviation is consistent with $4.6 \%$ and $8.8 \%$ extra value added. ${ }^{17}$

\subsection{Trade regimes and credit constraints}

\section{Firms' financial health}

We next examine the effect of credit constraints on exporters' choice of trade regimes. We first exploit the variation in financial health across firms within a sector. Given the cost and demand structure in an industry, we expect producers with more limited access to capital to concentrate foreign activity in processing trade, and pure assembly in particular. We then explore the variation in liquidity needs and ability to secure outside funds across sectors within firms. Conceptually, this allows us to infer how

\footnotetext{
${ }^{17}$ For completeness, we have also examined how firms' total exports and domestic sales vary with their choice of trade regime (Columns 1-2 of Appendix Table 1). Unsurprisingly, firms that undertake more processing trade report lower sales in China and higher export revenues. Among processing exporters, those that pursue pure assembly tend to sell less both at home and abroad than those who conduct import and assembly.
} 
financial considerations affect trade regime choices and the allocation of financial resources across sectors within multi-product exporters. As we discuss in Section 5.4, it also makes it possible to circumvent concerns with endogeneity and reverse causality.

We use two proxies for firms' financial health: liquidity and leverage. While the former captures firms' current availability of finance, the latter reflects producers' debt obligations and ability to raise additional capital. We thus believe exporters with high liquidity and low leverage to be less constrained. Armed with these two measures, we estimate the following specification ${ }^{18}$ :

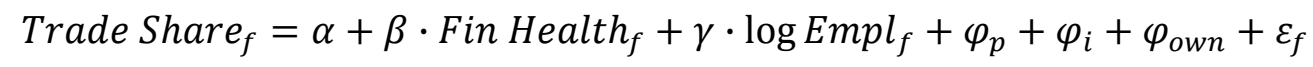

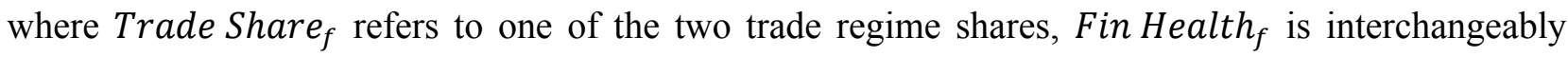
firm $f^{\prime}$ s liquidity or leverage, and $\varphi_{p}$ and $\varphi_{i}$ are province and industry fixed effects as before. We continue to condition on firm size and to report robust standard errors.

As the results in Table 4 indicate, exporters' liquidity and leverage ratios strongly predict their choice of trade regime. Consistently with Proposition 3, manufacturers with more financial resources and less short-term debt typically earn more of their foreign revenues from ordinary exports (Column 1). They also conduct a greater proportion of their processing trade with imported inputs as opposed to via pure assembly (Column 2). These findings are highly statistically significant and continue to hold when we lag firms' financial health by a year (Columns 3-4). Since the latter is less subject to endogeneity concerns, it is our preferred measure in the rest of the analysis. Similar results however obtain whether use concurrent or lagged indicators.

The effects we have identified appear to be economically meaningful. Improving liquidity (leverage) by one standard deviation would reduce the share of processing exports in total foreign sales by $0.8 \%(0.5 \%)$. The contribution of pure assembly towards processing exports would also drop by $1.2 \%(2.8 \%)$. For reference, the mean of these two trade shares is $30 \%$ and $19 \%$, respectively.

Since trade costs, demand conditions and the broader economic environment vary across China's export destinations, it is possible that different trade regimes are better suited to different markets for reasons unrelated to financial frictions. To ensure that our results are not driven by such factors, we construct exporters' trade shares separately for each of their destinations and re-estimate equation (2) adding country fixed effects. Because the unit of observation is now the firm-country pair and the error term might be correlated across markets within a supplier, we cluster errors by firm. Reassuringly, we obtain quantitatively and qualitatively similar results (Columns 5-6).

\footnotetext{
${ }^{18}$ In all specifications, we use the same symbols for the intercept, coefficients, fixed effects and error terms as in equation (1). This is only for expositional convenience; these objects will of course differ across specifications.
} 
Firms' proclivity for using different trade regimes might also vary across products for reasons unrelated to credit constraints, such as China's product-specific expertise or availability of specialized inputs. Specification (2) already conditions on the main industry affiliation of each exporter with industry fixed effects. In unreported regressions, we have further confirmed that our results hold at the finest level of disaggregation in the data: when the outcome variable is at the firm-product-destination level and we include both country dummies and 8-digit product code fixed effects.

As Figure 1 illustrates, a large proportion of Chinese manufacturers operate exclusively under one trade regime. For this reason, the export shares we use frequently take on a value of 0 or 1 . On average, about a quarter to a third of the observations in a given regression are associated with trade shares strictly between 0 and 1 . Our results continue to hold when we adopt a binary indicator variable instead of the continuous measure (left panel of Table 6). In these robustness checks, the trade share is set to 1 for all values above 0 . While we report point estimates based on a linear probability model, similar patterns emerge when we alternatively adopt Probit.

Recall from Section 3.6 that firms' heterogeneity in productivity can affect their export decisions directly (because of fixed costs) and indirectly (by determining access to finance). In order to shed light on these mechanisms, in Columns 7-8 of Table 4 we re-estimate (2) controlling explicitly for companies' productivity. ${ }^{19}$ The estimated coefficient on manufacturers' financial health largely retains its statistical and economic significance, while productivity enters negatively and significantly. This suggests that production efficiency is positively but imperfectly correlated with financial health, and impacts trade regime choices via both channels. In other words, both less productive firms and more liquidity constrained enterprises self-select into processing trade, and pure assembly in particular. Comparative statics indicate that the two firm characteristics have similar economic significance.

\section{Sectors' financial vulnerability}

We next turn to Proposition 2 and examine the variation in trade activity across sectors within firms. To this end, we exploit the detailed nature of the customs data and measure the contribution of different trade regimes for each firm-sector pair. We adopt the following estimating equation:

$$
\text { Trade Share }_{f i}=\alpha+\beta \cdot \text { Fin Vuln }_{i}+\gamma \cdot \text { Ind Controls }_{i}+\varphi_{f}+\varepsilon_{f i}
$$

Here Trade Share $_{f i}$ corresponds to a relevant export ratio for firm $f$ in industry $i$, while Fin Vuln $i$ is one of four alternative measures of sectors' financial vulnerability. Since the unit of observation is now

\footnotetext{
${ }^{19}$ We obtain very similar results whether we measure productivity according to Levinsohn and Petrin (2003) or with value added per worker.
} 
at the firm-industry level, we are able to include firm fixed effects $\varphi_{f}$. These control for a range of observed and unobserved firm characteristics that can affect trade outcomes in all industries, including financial health, productivity, size, ownership type, familiarity with foreign markets, etc. The effect of Fin $\operatorname{Vuln}_{i}$ is thus identified purely from the variation across sectors within multi-sector producers. It indirectly reflects the way in which exporters allocate financial resources across trade modes and industries with different liquidity needs.

Note that this specification does not permit industry fixed effects. We nevertheless want to ensure that any impact of financial vulnerability we identify does not capture the role of other sector characteristics that might influence firms' choice over trade regimes for reasons unrelated to credit constraints. For this reason, we condition on industry's physical and human capital intensity, as well as the importance of relationship-specific investments in input production. These control variables come from Braun (2003) and Nunn (2007). We once again cluster errors by firm, to account for the potential correlation in cost or demand shocks across sectors within firms.

As evident in Table 5, the results from this stringent specification strongly suggest that exporters choose different means of servicing foreign markets based on the financial characteristics of the sector. Firms actively pursue processing trade, and pure-assembly in particular, in industries with high working capital requirements as proxied by the inventories-to-sales ratio (Columns 1-2 in Panel A). Increasing short-run liquidity needs by $20 \%$ would translate into a $10 \%$ rise in the share of foreign revenues generated through processing trade. It would also imply a $4 \%$ growth in the share of pure assembly in processing exports.

We next examine the importance of sectors' reliance on outside finance for long-term investment (i.e. capital and R\&D expenditures). As anticipated, industries' external capital dependence and $R \& D$ intensity are both strong predictors of the choice between ordinary and processing trade (Panels B and C). The trade-off between pure assembly and processing with imports, on the other hand, appears unrelated to the financing of long-run capital projects. These results are consistent with the presumption that the two processing regimes differ only with regard to the financing of short-run variable input costs. By contrast, fixed distribution costs and equipment constitute a key distinction between processing and ordinary exporting.

We finally turn to industries' asset tangibility in Panel D. While the three sector measures above capture liquidity needs, tangibility reflects the capacity to raise capital by pledging collateral. Our results confirm that exporters are indeed more likely to choose processing over ordinary exports in industries with softer assets (Column 1). As the financing of long-term investment, asset tangibility too appears unimportant for the distinction between the two processing methods (Column 2). 
Even within narrowly defined industry categories, the optimal choice of trade regime might respond to characteristics of the export market. To account for this possibility, we re-estimate (3) with the firm-sector-destination as the unit of observation and include country fixed effects (Columns 3-4). As another robustness check, we also consider a binary specification in which we set the trade share equal to 1 for all values above 0 (right panel of Table 6). Our findings remain equally strong in these alternative specifications. In unreported regressions, we have finally confirmed that similar results obtain when we use the full granularity of the data and construct the outcome variable for each firmproduct-destination triplet instead of at the firm-sector-destination level.

\subsection{Additional corroborative evidence}

While the patterns we have documented go a long way towards establishing a causal effect of financial constraints on firms' trade regime choice, further support for the mechanisms in the model would help solidify our interpretation. We now offer four additional pieces of evidence.

\section{Financial development across Chinese regions}

The financial sector in China is known to be quite segmented, with banks typically serving firms located in the same geographic region (World Bank 2005). This generates variation in the availability of external capital across Chinese provinces that is largely exogenous from the perspective of individual producers. We thus expect the export decisions of manufacturers located in financially more developed areas to be less sensitive to firms' financial health and sectors' financial vulnerability.

In other words, producers with low liquidity should be able to conduct less processing trade (especially pure assembly) if located in financially more advanced parts of China than if based in financially less advanced regions. To test this hypothesis, we expand specification (2) to include the interaction of firm liquidity with a measure of financial development in the firms' home province. In addition, across sectors within a firm, sectors with higher liquidity needs should exhibit less processing exports (especially pure assembly) if the firm is in a financially developed region than if it is in an underdeveloped area. To test this hypothesis, we expand specification (3) to include the interaction of sectors' inventory-to-sales ratio with a measure of financial development in the firms' home province. We estimate the following two regressions:

$$
\begin{aligned}
& \text { Trade Share }_{f d}=\alpha+\beta \cdot \text { Fin Health }_{f}+\gamma \cdot \text { Fin Health }_{f} \cdot \text { High Fin Devt }_{p}+ \\
& +\delta \cdot \log E m p l_{f}+\varphi_{p}+\varphi_{i}+\varphi_{o w n}+\varphi_{d}+\varepsilon_{f d} \\
& \text { Trade Share }_{f d i}=\alpha+\beta \cdot \text { Fin Vuln }_{i}+\gamma \cdot \text { Fin Vuln }_{i} \cdot \text { High Fin Devt }_{p}+
\end{aligned}
$$




$$
+\delta \cdot \text { Ind Controls }{ }_{i}+\varphi_{f}+\varphi_{d}+\varepsilon_{f d i}
$$

Here High Fin Devt $p_{p}$ is a dummy variable equal to 1 for provinces with financial development above the sample median and all other variables are defined as before. To exploit the granularity in the data, the unit of observation in (4) is the firm-destination pair, while that in (5) is the firm-sector-destination triplet. In keeping with our earlier specifications, we include province $\varphi_{p}$, industry $\varphi_{i}$ and ownership $\varphi_{\text {own }}$ fixed effects in (4) (where, as before, we use information on the firm's primary industry from the census data). By contrast, (5) exploits purely the variation across sectors within exporters by conditioning on firm fixed effects $\varphi_{f}$. The main effect of High Fin Devt is thus subsumed by the province or firm fixed effect, respectively. Finally, both specifications include destination fixed effects $\varphi_{d}$ to account for systematic differences across export markets. We once again cluster errors by firm to allow for correlated errors across the multiple sectors and countries in which the company conducts business.

We report our results in Table 7. Following common practice in the literature, we proxy regional financial conditions with the ratio of total credit to GDP from the Almanac of China's Finance and Banking. Firms' financial health and sectors' financial dependence enter with the same sign and significance as before. Importantly, the interaction terms are also significant and of the opposite sign, as anticipated. These results obtain whether we use continuous or binary trade shares as the outcome variable. Comparing the point estimates on $\beta$ and $\gamma$, we conclude that the effect of firms' financial health on their proclivity to undertake processing trade is twice as high in financially underdeveloped regions in China as it is in financially advanced provinces. Increasing a sector's working capital needs by $10 \%$ leads firms to increase their processing exports by $10.3 \%$ if they face a weak banking system, but by only $3.5 \%$ if they have access to strong capital markets.

We have confirmed the robustness of these results to a number of specification checks (available on request). First, we added industry fixed effects in (5) to absorb unobserved industry characteristics. We then identify only the interaction term, but not the main effect of Fin Vuln Second, we included additional interaction terms between the financial variables (financial health or financial vulnerability) and regional income per capita. This ensures that we isolate the effect of financial development separately from that of overall economic development. Finally, we controlled for the interaction of regional relative capital (skill) endowment and sectors' capital (skill) intensity. Reassuringly, our findings remain qualitatively unchanged with these extra controls. 


\section{Financial development across export destinations}

Our theoretical and empirical analysis has considered the optimal choice of trade regime from the exporter's point of view. Whether the Chinese producer is able to pursue processing with imports or pure assembly also depends on the incentives and ability of the foreign buyer to enter into such a contractual arrangement. All else constant, the foreign buyer would be more willing to engage in PA or PI if he has easier access to financial resources. This implies that financial development in the destination country would have the opposite impact on the exporter's trade regime choice to that of financial development in his home province.

We test this hypothesis by repeating the analysis in (4) and (5), this time using interactions with a dummy equal to 1 for export markets with financial development above the median $\left(\right.$ High Fin Devt $\left._{d}\right)$. For consistency, we measure the latter with the amount of credit by banks and other financial intermediaries to the private sector as a share of GDP, using the World Bank's Financial Structure database. The results in Table 8 suggest that superior financial development in the destination market indeed makes it more likely for exporters to choose processing trade, and especially pure assembly, in sectors with higher working capital needs. The impact of increasing industries' inventory ratio on firms' processing trade shares is doubled if their trade partner is based in a country with above-average private credit relative to a country with below-average private credit. On the other hand, the strength of the financial system in the export market does not appear to modify the effect of limited liquidity at the level of the firm.

\section{Relationship specificity across sectors}

In our model, financial constraints affect trade regime choice and ultimately firm profitability in part because investments are fully relationship-specific. In reality, the extent of relationship specificity varies across sectors and could affect firms' ability to raise external capital. The better an outsider can ascertain the level of investment, the easier it might be for external financiers to monitor producers' effort. ${ }^{20}$ Similarly, the higher the value of the inputs or assembly task outside the partnership, the greater the expected return to an investor in case of default as he could seize and liquidate these assets more profitably. Both of these mechanisms would increase lenders' willingness to fund the operations of the Chinese producer. This suggests that financial considerations should affect firms' choice of trade regime relatively more in industries that are more intensive in relationship-specific investments. We find results broadly consistent with this prior when we interact firms' financial health or sectors'

\footnotetext{
${ }^{20}$ See Antràs et al. (2009) for a formal model of a similar mechanism.
} 
financial dependence with sectors' relationship specificity in Table 9. This table replicates the analysis in (4) and (5) using a dummy for industries with relationship specificity above the sample median.

\section{Import trade regimes}

While our analysis has focused on firms' export trade regime, our model has clear predictions for their import strategies as well. In particular, manufacturers that record more processing exports (pure assembly) should also use more foreign materials imported under the processing regime (pure assembly). Table 10 confirms that this is indeed the case. ${ }^{21}$ We now construct the $\frac{X_{P A}+X_{P I}}{X_{P A}+X_{P I}+X_{O T}}$ and $\frac{X_{P A}}{X_{P A}+X_{P I}}$ shares twice for each firm, once based on its exports and once based on its imports. Regressing the latter on the former, we obtain highly significant positive coefficients even conditioning on province, industry and ownership fixed effects (Column 1). Consistently with the model, creditconstrained firms with low liquidity and high leverage are not only more likely to export under processing trade, and pure assembly in particular (Table 4), but also more likely to import under processing trade, and pure assembly in particular (Table 10). This last result holds controlling for firm size and productivity in addition to the fixed effects mentioned above.

\subsection{Endogeneity}

Our identification strategy has relied on exploiting the variation in liquidity constraints across firms and the variation in financial vulnerability across sectors. We believe this allows us to establish a causal effect of financial frictions on exporters' trade regime choices and consequently on profitability. In particular, our empirical approach makes it possible to circumvent two potential concerns with endogeneity and reverse causality.

The first such concern involves the estimated relationship between producers' financial health and relevant trade shares. In the absence of frictions in capital markets, manufacturers would be free to raise the necessary finance for their optimal export strategy. Since liquidity needs decline as suppliers re-orient activity from ordinary trade to processing with imports to pure assembly, so would their observed usage of capital. This could potentially explain our findings for exporters' liquidity and leverage. We argue that this is an unlikely explanation for two reasons. First, our results are robust to using lagged values of these balance sheet variables that are arguably less subject to this concern. Second and more importantly, we document substantially higher profits from import-and-assembly relative to pure assembly, and even greater returns to ordinary trade. Were Chinese exporters

${ }^{21}$ Firms that conduct more processing exports, and pure assembly in particular, report not just higher shares of processing imports, but also higher absolute levels of processing imports (Column 3 of Appendix Table 1). 
financially unconstrained, they would have therefore preferred to pursue these more profitable regimes. That they don't is strong confirmation that limited access to capital indeed distorts companies' trade choices and ultimately performance.

The second potential concern with reverse causality is more subtle. Consider the possibility that firms sort into different trade regimes for reasons unrelated to financial considerations. Assume further that profitability falls with the share of processing exports, and pure assembly in particular, as we have established. If financiers are more willing to fund more profitable ventures, exporters more active in trade regimes with lower returns would record lower liquidity and higher leverage ratios. Once again, this could provide an alternative explanation for the link between firms' financial health and trade shares in Table 4. This rationalization, however, would fail to account for the systematic variation in cross-border activity we document across sectors within a given exporter. The industry measures of financial vulnerability are by construction exogenous from the perspective of individual firms and reflect sector characteristics innate to the nature of the manufacturing process. Their important effect on how entrepreneurs choose to service foreign markets signals that financial considerations are of great consequence. The additional results in the previous subsection further bolster this conclusion: It would be difficult for reverse causality to generate the stronger effects we find in Chinese regions with weaker bank systems, in financially more advanced destinations, and in sectors more intensive in relationship-specific investments.

\section{Quantifying the Aggregate Distortion}

Our results indicate that credit constraints restrict firms to low value-added stages of the supply chain and thereby preclude them from pursuing more profitable opportunities. This suggests that strengthening capital markets can be instrumental in increasing aggregate value added, profits and presumably income levels in developing countries. An important policy question is the magnitude of these effects. In this section, we use our point estimates to quantify the potential gains from relaxing financial frictions in China arising through the reallocation away from processing trade.

We consider a counterfactual scenario in which the financial health of all firms in the sample were to improve to that of the least constrained company. If a producer's actual liquidity ratio is $L i q_{f}$, its measured financial health would therefore increase by $L i q_{M A X}-L i q_{f}$ under this scenario. As a result, the firm would reduce its share of processing exports by $\beta_{l i q}^{P T} \cdot\left(L i q_{M A X}-L i q_{f}\right)$, where $\beta_{l i q}^{P T}$ is the coefficient from regressing $\frac{X_{P A}+X_{P I}}{X_{P A}+X_{P I}+X_{O T}}$ on liquidity in equation (2) and Table 4. In addition, the exporter's share of processing trade conducted via pure assembly would decline by $\beta_{l i q}^{P A} \cdot\left(\operatorname{Liq}_{M A X}-\right.$ 
$L i q_{f}$ ), where $\beta_{\text {liq }}^{P A}$ is now the coefficient from regressing $\frac{X_{P A}}{X_{P A}+X_{P I}}$ on liquidity. Let the point estimates on the processing trade share in equation (1) and Table 3 be $\beta_{P T}^{\pi}, \beta_{P T}^{\pi / r}$ and $\beta_{P T}^{V A}$ for the effect on log profits, profit-to-sales ratio and log value added, respectively. Denote the corresponding estimates for the share of pure assembly in processing exports as $\beta_{P A}^{\pi}, \beta_{P A}^{\pi / r}$ and $\beta_{P A}^{V A}$. The total rise in aggregate Chinese profits $\Delta \Pi^{\text {China }}$ and value added $\Delta V A^{\text {China }}$ can therefore be calculated as:

$$
\begin{aligned}
& \Delta \Pi_{1}^{\text {China }}=\sum_{f} \beta_{P T}^{\pi} \cdot \beta_{\text {liq }}^{P T} \cdot\left(L i q_{M A X}-L i q_{f}\right) \cdot \pi_{f}+\sum_{f, P T>0} \beta_{P A}^{\pi} \cdot \beta_{l i q}^{P A} \cdot\left(L i q_{M A X}-L i q_{f}\right) \cdot \pi_{f} \\
& \Delta \Pi_{2}^{\text {China }}=\sum_{f} \beta_{P T}^{\pi / r} \cdot \beta_{\text {liq }}^{P T} \cdot\left(L i q_{M A X}-L i q_{f}\right) \cdot r_{f}+\sum_{f, P T>0} \beta_{P A}^{\pi / r} \cdot \beta_{l i q}^{P A} \cdot\left(L i q_{M A X}-L i q_{f}\right) \cdot r_{f} \\
& \Delta \mathrm{VA}^{\text {China }}=\sum_{f} \beta_{P T}^{V A} \cdot \beta_{l i q}^{P T} \cdot\left(L i q_{M A X}-L i q_{f}\right) \cdot v a_{f}+\sum_{f, P T>0} \beta_{P A}^{V A} \cdot \beta_{l i q}^{P A} \cdot\left(L i q_{M A X}-L i q_{f}\right) \cdot v a_{f}
\end{aligned}
$$

The term inside each summation represents the boost to firm $f$ 's profits and value added associated with its enhanced access to capital. The first summation in each expression captures the improvement in firm performance associated with shifting activity away from processing trade towards ordinary exports. The second in turn reflects the gains from relocating processing trade from pure assembly to processing with imports, for firms that report processing trade $(P T>0)$. Summing across all firms in the sample delivers estimates of economy-wide outcomes.

Since value added enters the regression in $\log$ form, $\beta_{i}^{V A} \cdot \beta_{l i q}^{i} \cdot\left(L i q_{M A X}-L i q_{f}\right)$ captures the percent change in $f$ 's value added. Multiplying it by $f$ 's level of value added $v a_{f}$ thus gives the change in absolute terms. Turning to profits, there are two ways to infer their rise. The regression for log profits motivates the first approach, $\Delta \Pi_{1}^{\text {China }}$, which follows the same logic as $\Delta V A^{\text {China }}$. However, only firms with positive reported profits enter this regression. Because relaxing credit constraints can bring some companies from negative to positive profits, $\Delta \Pi_{1}^{\text {China }}$ is likely an underestimate. The regression for the profit-to-sales ratio, on the other hand, spans all firms in the sample and permits a more accurate calculation. Since $\beta_{i}^{\pi / r} \cdot \beta_{\text {liq }}^{i} \cdot\left(L i q_{M A X}-L i q_{f}\right)$ reflects the change in firm $f$ 's profit-tosales ratio, we multiply it by $f$ 's observed revenues $r_{f}$ to obtain the rise in its profits.

We find that the removal of liquidity constraints would increase aggregate Chinese profits and value added by $\Delta \Pi_{2}^{\text {China }}=5.5$ billion $\mathrm{RMB}$ and $\Delta \mathrm{VA}^{\text {China }}=15.2$ billion $\mathrm{RMB}$ as a result of changes in firms' trade activity. These magnitudes are large in absolute levels and imply that total Chinese profits and value added would grow by $1.3 \%$ and $0.7 \%$, respectively.

While informative, this quantification is subject to some caveats. First, these estimates are based on reduced-form analysis that might not accurately capture the general equilibrium effects of 
financial development. If more firms undertake ordinary trade, external economies of scale could generate bigger profit and value added gains, for example via access to more specialized inputs or better transportation and marketing infrastructure. On the other hand, increased competition among ordinary exporters could lower profit margins, assuming that the elasticity of substitution is higher for products produced under the same trade regime than for products made under different trade modes.

Second, our results are based on the sample of firms with matched customs and census data. Given that the matched sample appears representative and covers $30 \%$ of all companies in the customs registry, 5.5/0.3 $=18.3$ bil $\mathrm{RMB}$ and 15.2/0.3 = 50.7bil RMB might be closer to the predicted change in aggregate profits and value added in levels. On the other hand, we expect the relative change in terms of growth rates to be the same. Separately, calculation (6) ignores producers with no trade activity. Evidence in the prior literature suggests that such manufacturers might be more credit constrained than those able to export. If financial development facilitates entry into exporting, the latter could make additional contributions to total profits and value added.

Third, the counterfactual we consider brings all firms to the financial health of the least constrained Chinese firm. Given that China's level of financial development is inferior to that in many rich countries, an overall improvement in its financial system could increase firms' access to capital to a much greater degree than that currently enjoyed by the least constrained company. This would presumably translate into higher gains than we estimate.

Finally, we emphasize that our estimates capture the gains from relaxing financial frictions channeled only through the reallocation of activity across trade regimes. There are of course other channels through which removing credit constraints could improve profits and value added which our calculation ignores.

\section{Conclusion}

This paper examines why firms choose to service foreign markets via ordinary or processing trade and how this decision affects export profitability. Using matched customs and balance sheet data on the universe of Chinese exporters, we establish two empirical facts. First, export profitability varies systematically across companies with different trading strategies. In particular, profits, profitability and value added decrease as producers re-orient sales from ordinary towards processing trade, and from import-and-assembly towards pure assembly. Second, exporters' productivity and financial health together determine their export mode decisions. More productive firms and less liquidity constrained firms are more likely to pursue ordinary trade relative to processing exports, and import and assembly 
relative to pure assembly. We rationalize these results with a model of international trade that incorporates credit constraints and imperfect contractibility in companies' choice over trade regimes.

Our findings suggest that financial frictions influence the design of international trade contracts and the organization of production across firm and country boundaries. We thus highlight a novel mechanism through which liquidity constraints impact firms' export outcomes and ultimately profitability. In particular, our analysis illustrates how weak financial institutions restrict firms to lowvalued added stages of the supply chain and to less profitable assembly tasks for processing exports. This implies that strengthening financial markets in developing countries can be instrumental in increasing aggregate value added, profits and presumably income levels. Our conclusions also shed new light on the gains from trade in the context of trade in intermediate goods, as well as on the distributional consequences of trade policy in the presence of financial frictions. More broadly, we provide one of the first studies of processing trade and thus inform current discussions of the effects of

global production chains on optimal trade policy, exchange-rate pass-through and the transmission of supply and demand shocks across nations.

\section{References}

Ahn, J.B., Khandelwal, A. and S.-J. Wei (2011). "The Role of Intermediaries in Facilitating Trade." Journal of International Economics 84(1), p.73-85.

Amiti, M. and D. Weinstein (2011). "Exports and Financial Shocks.” Quarterly Journal of Economics 126(4).

Antràs, P., Desai, M. and F. Foley (2009). "Multinational Firms, FDI Flows and Imperfect Capital Markets." Quarterly Journal of Economics 124(3), p.1171-219.

Antràs, P. and F. Foley (2011). "Poultry in Motion: A Study of International Trade Finance Practices." NBER Working Paper 17091.

Antràs, P. and R. Staiger (2011). "Offshoring and the Role of Trade Agreements." American Economic Review (forthcoming).

Bems, R., Johnson, R.C. and K.M. Yi (2010). "Vertical Linkages in the Collapse of Global Trade." American Economic Review Papers and Proceedings 101(3), p.308-12.

Berman, N. and J. Héricourt (2008). "Financial Factors and the Margins of Trade: Evidence from Cross-Country Firm-Level Data." CES Working Paper 2008.50.

Braun, M. (2003). "Financial Contractibility and Asset Hardness." University of California - Los Angeles mimeo.

Bricongne, J.C., Fontagne, L., Gaulier, G., Taglioni, D. and V. Vicard (2010). "Firms and the Global Crisis: French Exports in the Turmoil." Bank of France mimeo.

Chor, D. and K. Manova (2012). "Off the Cliff and Back: Credit Conditions and International Trade during the Global Financial Crisis." Journal of International Economics 87, p.117-133. 
Claessens, S. and L. Laeven (2003). "Financial Development, Property Rights, and Growth." Journal of Finance 58(6), p.2401-37.

Dai, M., Maitra, M. and M. Yu (2011). "Unexceptional Exporter Performance in China? The Role of Processing Trade." Peking University mimeo.

Ding, S., Guariglia, A. and Knight, J. "Investment and Financing Constraints in China: Does Working Capital Management Make a Difference?" Journal of Banking and Finance (forthcoming).

Fazzari, S. and B. Petersen (1993). "Working Capital and Fixed Investment: New Evidence on Financing Constraints." Rand Journal of Economics 24, p.328-42.

Feenstra, R. and G. Hanson (2005). "Ownership and Control in Outsourcing to China: Estimating the Property-Rights Theory of the Firm." Quarterly Journal of Economics 120(2), p.729-61.

Fernandes, A. and H. Tang (2012). "Determinants of Vertical Integration in Export Processing: Theory and Evidence from China." Journal of Development Economics 99(2), p.396-414.

Goldberg, P., Khandelwal, A., Pavcnik, N. and P. Topalova (2010). "Imported Intermediate Inputs and Domestic Product Growth: Evidence from India." Quarterly Journal of Economics 125(4), p.172767.

Greenaway, Guariglia and R. Kneller (2007). "Financial Factors and Exporting Decisions." Journal of International Economics 73(2), p.377-95.

Grossman, S. and O. Hart (1986). "The Costs and Benefits of Ownership: A Theory of Vertical and Lateral Integration." Journal of Political Economy 44, p.691-719.

Hart, O. and J. Moore (1990). "Property Rights and the Nature of the Firm." Journal of Political Economy 48, p.1119-58.

Johnson, R. (2011). "Accounting for Intermediates: Production Sharing and Trade in Value Added." Journal of International Economics (forthcoming).

Kim, S. and H. S. Shin (2012). "Working Capital, Inventories and Optimal Offshoring." Princeton University mimeo.

Klingebiel, D., Kroszner, R. and L. Laeven (2007). "Banking Crises, Financial Dependence, and Growth." Journal of Financial Economics 84(1), p.187-228.

Kugler, M. and E. Verhoogen (2008). "Prices, Plant Size, and Product Quality." Review of Economic Studies (forthcoming).

Kugler, M. and E. Verhoogen (2009). "Plants and Imported Inputs: New Facts and an Interpretation." American Economic Review Papers and Proceedings 99(2), p.501-507.

Lemoine, F. and D. Ünal-Kesenci (2004). "Assembly Trade and Technology Transfer: The Case of China." World Development 32(5), p.829-50.

Levchenko, A., Lewis, L. and L. Tesar (2010). "The Collapse of International Trade during the 20082009 Crisis: In Search of the Smoking Gun." IMF Economic Review 58, p.214-53.

Levinsohn, J. and A. Petrin (2003). "Estimating Production Functions Using Inputs to Control for Unobservables." Review of Economic Studies 70(2), p.317-42.

Manova, K. (2007). "Credit Constraints, Heterogeneous Firms, and International Trade." Review of Economic Studies (forthcoming).

Manova, K. and Z. Zhang (2008). "China's Exporters and Importers: Firms, Products, and Trade Partners.” NBER Working Paper 15249. 
Manova, K. and Z. Zhang (2012). "Export Prices across Firms and Destinations.” Quarterly Journal of Economics 127, p.379-436.

Manova, K., Wei, S.-J. and Z. Zhang (2009). "Firms Exports and Multinational Activity under Credit Constraints.” NBER Working Paper 16905.

Melitz, M. (2003). "The Impact of Trade on Intra-Industry Reallocations and Aggregate Industry Productivity." Econometrica 71(6), p.1695-725.

Minetti, R. and S.C. Zhu (2011). "Credit constraints and firm export: microeconomic evidence from Italy." Journal of International Economics 83, p.109-25.

Nunn, N. (2007). "Relationship-Specificity, Incomplete Contracts, and the Pattern of Trade." Quarterly Journal of Economics 122(2), p.569-600.

Rajan, R. and L. Zingales (1998). "Financial Dependence and Growth." American Economic Review 88, p.559-86.

Wang. Z. and Z. Yu (2011). "Trading Partners, Traded Products, and Firm Performance of China's Exporter-Importers: Does Processing Trade Make a Difference?" World Economy (forthcoming).

Whited, T. (1992). "Debt, Liquidity Constraints and Corporate Investment: Evidence from Panel Data." Journal of Finance 47, p.1425-60.

World Bank (2005). "China: Integration of National Product and Factor Markets, Economic Benefits and Policy Recommendations." Washington, DC.

Yu, M. (2011). "Processing Trade, Firm Productivity, and Tariff Reductions: Evidence from Chinese Products." Peking University mimeo. 
Table 1. Trade Regime Characteristics

This table summarizes the costs, revenues and profits associated with different export trade regimes in the model.

\begin{tabular}{|c|c|c|c|}
\hline & Ordinary Trade & Import \& Assembly & Pure Assembly \\
\hline \multicolumn{4}{|l|}{ Costs to Chinese Exporter } \\
\hline Chinese Inputs & $C_{D}$ & $C_{D}$ & $C_{D}$ \\
\hline Foreign Inputs & $(1+\tau) C_{F}$ & $C_{F}$ & 0 \\
\hline Distribution Network & $F$ & 0 & 0 \\
\hline \multicolumn{4}{|l|}{ Costs to Foreign Buyer } \\
\hline Foreign Inputs & 0 & 0 & $C_{F}$ \\
\hline Distribution Network & 0 & $F$ & $F$ \\
\hline Import Tariff Rebate & $\tau C_{F}$ & 0 & 0 \\
\hline Export Revenues & $R$ & $R$ & $R$ \\
\hline Surplus From Relationship & $R-C_{D}-C_{F}-F$ & $R-C_{D}-C_{F}-F$ & $R-C_{D}-C_{F}-F$ \\
\hline Exporter's Bargaining Weight & $\beta_{O T}=1$ & $\beta_{P I}=\frac{C_{D}+C_{F}}{C_{D}+C_{F}+F}$ & $\beta_{P A}=\frac{C_{D}}{C_{D}+C_{F}+F}$ \\
\hline Exporter's Profits & $R-C_{D}-C_{F}-F$ & $\beta_{P I}\left(R-C_{D}-C_{F}-F\right)$ & $\beta_{P A}\left(R-C_{D}-C_{F}-F\right)$ \\
\hline Exporter's Liquidity Needs & $C_{D}+(1+\tau) C_{F}+F$ & $C_{D}+C_{F}$ & $C_{D}$ \\
\hline
\end{tabular}




\section{Table 2. Summary Statistics}

This table provides summary statistics for all firms in the matched sample (Columns 1-3), all firms in the census data (Columns 4-6), and all firms in the customs data (Columns 7-9). Productivity is constructed as value added per worker (VA) or according to Levinsohn-Petrin (2003) (LP). Firms' financial health is measured by liquidity $=($ current assets - current liability $) /$ total assets or leverage $=$ short-term debt $/$ current assets. PA, PI and OT represent the value of exports under pure assembly, processing with imports, and ordinary trade respectively.

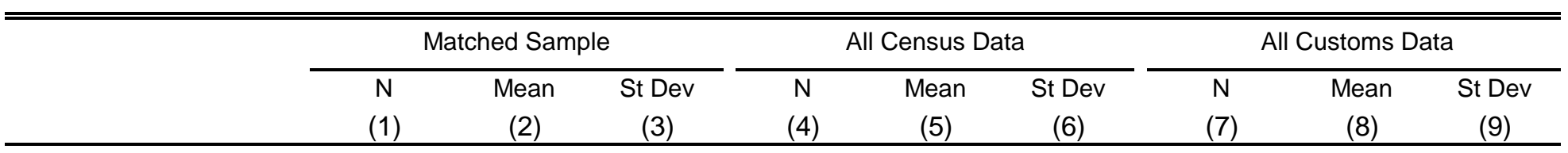

Balance Sheet Data

$\begin{array}{lcccccc}\text { (log) Sales } & 50,567 & 10.64 & 1.35 & 75,001 & 10.43 & 1.36 \\ \text { (log) Employment } & 50,606 & 5.31 & 1.14 & 75,017 & 5.20 & 1.15 \\ \text { (log) Profits } & 39,844 & 7.33 & 1.95 & 60,558 & 7.06 & 1.95 \\ \text { Profits / Sales } & 50,582 & 0.03 & 0.20 & 75,017 & 0.03 & 0.23 \\ \text { (log) Value Added } & 49,801 & 9.23 & 1.48 & 73,944 & 9.03 & 1.48 \\ \text { Productivity (LP) } & 47,297 & 4.96 & 1.17 & 64,779 & 4.93 & 1.15 \\ \text { Productivity (VA) } & 49,735 & 3.93 & 1.08 & 73,819 & 3.84 & 1.05 \\ \text { Liquidity } & 50,574 & 0.09 & 0.32 & 74,974 & 0.09 & 0.33 \\ \text { Leverage } & 50,567 & 0.99 & 1.28 & 74,957 & 1.01 & 1.41\end{array}$

\section{Customs Data: Firm Level}

$\begin{array}{lccc}\text { (log) Total Exports } & 50,606 & 13.83 & 2.08 \\ \text { (log) Total Imports } & 31,551 & 12.65 & 2.90 \\ \text { (PA+PI) / (PA+PI+OT) } & 50,522 & 0.30 & 0.42 \\ \text { PA / (PA+PI) } & 22,071 & 0.19 & 0.37\end{array}$

$\begin{array}{rcc}114,883 & 13.00 & 2.26 \\ 60,330 & 12.21 & 2.84 \\ 114,883 & 0.27 & 0.41 \\ 42,176 & 0.24 & 0.41 \\ & & \\ & & \\ 258,658 & 10.96 & 3.22 \\ 76,964 & 10.98 & 3.36 \\ 258,658 & 0.18 & 0.37 \\ 60,553 & 0.21 & 0.40\end{array}$

Customs Data: Firm-Industry Leve

105,895

(log) Total Imports 40,556

(PA+PI) / (PA+PI+OT) 105,895

$11.47 \quad 3.56$

$\mathrm{PA} /(\mathrm{PA}+\mathrm{PI})$

$32,576 \quad 0.16$

$\begin{array}{lll}60,553 & 0.21 & 0.40\end{array}$ 
Table 3. Trade Regimes, Firm Profitability and Value Added

Notes: PA, PI and OT denote pure assembly, processing with imports, and ordinary trade, respectively. Pure exporters are firms that export only but do not sell domestically. T-statistics based on robust standard errors reported in parenthesis. ***, **, and * indicate significance at the $1 \%, 5 \%$, and $10 \%$ level.

\begin{tabular}{|c|c|c|c|c|c|c|}
\hline \multirow[b]{2}{*}{ Dep Variable: } & \multicolumn{3}{|c|}{ All Firms } & \multicolumn{3}{|c|}{ Pure Exporters } \\
\hline & $\begin{array}{l}\text { (log) Profit } \\
(1)\end{array}$ & $\begin{array}{c}\text { Profit/Sales } \\
\text { (2) }\end{array}$ & $\begin{array}{l}\text { (log) Value Added } \\
\text { (3) }\end{array}$ & $\begin{array}{l}\text { (log) Profit } \\
\text { (4) }\end{array}$ & $\begin{array}{l}\text { Profit/Sales } \\
\text { (5) }\end{array}$ & $\begin{array}{c}\text { (log) Value Added } \\
\text { (6) }\end{array}$ \\
\hline \multicolumn{7}{|c|}{ Panel A. Processing Trade vs. Ordinary Trade } \\
\hline$(\mathrm{PA}+\mathrm{PI}) /(\mathrm{PA}+\mathrm{PI}+\mathrm{OT})$ & $\begin{array}{l}-0.151^{\star \star \star} \\
(-5.94)\end{array}$ & $\begin{array}{l}-0.016^{\star \star \star} \\
(-6.65)\end{array}$ & $\begin{array}{l}-0.108^{\star \star \star} \\
(-7.19)\end{array}$ & $\begin{array}{l}-0.221^{\star \star \star} \\
(-3.97)\end{array}$ & $\begin{array}{l}-0.023^{\star \star \star} \\
(-5.63)\end{array}$ & $\begin{array}{l}-0.149 * \star \star \\
(-4.92)\end{array}$ \\
\hline (log) Employment & $\begin{array}{l}0.905^{\star \star \star} \\
(116.61)\end{array}$ & $\begin{array}{l}0.007^{\star \star \star} \\
(8.68)\end{array}$ & $\begin{array}{l}0.896^{\star \star \star} \\
(182.28)\end{array}$ & $\begin{array}{l}0.808^{\star \star \star} \\
(46.33)\end{array}$ & $\begin{array}{l}0.007^{\star \star \star} \\
(5.14)\end{array}$ & $\begin{array}{l}0.825^{\star \star \star} \\
(78.17)\end{array}$ \\
\hline $\begin{array}{l}\text { R-squared } \\
\text { \# observations }\end{array}$ & $\begin{array}{l}0.39 \\
39,784\end{array}$ & $\begin{array}{l}0.03 \\
50,498\end{array}$ & $\begin{array}{l}0.55 \\
49,717\end{array}$ & $\begin{array}{l}0.35 \\
8,048\end{array}$ & $\begin{array}{l}0.14 \\
10,578\end{array}$ & $\begin{array}{l}0.54 \\
10,491\end{array}$ \\
\hline \multicolumn{7}{|c|}{ Panel B. Pure Assembly vs. Import \& Assembly } \\
\hline $\mathrm{PA} /(\mathrm{PA}+\mathrm{PI})$ & $\begin{array}{l}-0.275^{\star \star \star} \\
(-7.14)\end{array}$ & $\begin{array}{l}-0.013^{\star \star \star} \\
(-3.42)\end{array}$ & $\begin{array}{l}-0.229 * \star \star \\
(-10.74)\end{array}$ & $\begin{array}{l}-0.289 \star \star \star \\
(-4.05)\end{array}$ & $\begin{array}{l}-0.019 * \star \star \\
(-2.72)\end{array}$ & $\begin{array}{l}-0.227^{\star \star \star} \\
(-6.18)\end{array}$ \\
\hline (log) Employment & $\begin{array}{l}0.892^{\star \star \star} \\
(77.63)\end{array}$ & $\begin{array}{l}0.008^{\star \star \star} \\
(7.81)\end{array}$ & $\begin{array}{l}0.909 * \star \star \\
(125.99)\end{array}$ & $\begin{array}{l}0.830 * \star \star \\
(38.10)\end{array}$ & $\begin{array}{l}0.007^{\star \star \star} \\
(4.81)\end{array}$ & $\begin{array}{l}0.877^{\star \star \star} \\
(68.80)\end{array}$ \\
\hline $\begin{array}{l}\text { R-squared } \\
\text { \# observations }\end{array}$ & $\begin{array}{l}0.44 \\
16,603\end{array}$ & $\begin{array}{l}0.05 \\
22,063\end{array}$ & $\begin{array}{l}0.58 \\
21,704\end{array}$ & $\begin{array}{l}0.40 \\
4,876\end{array}$ & $\begin{array}{l}0.17 \\
6,771\end{array}$ & $\begin{array}{l}0.58 \\
6,708\end{array}$ \\
\hline Ownership FE & $\mathrm{Y}$ & Y & Y & Y & Y & Y \\
\hline Province FE, Industry FE & $\mathrm{Y}$ & $\mathrm{Y}$ & $\mathrm{Y}$ & $\mathrm{Y}$ & $\mathrm{Y}$ & $\mathrm{Y}$ \\
\hline
\end{tabular}




\section{Table 4. Trade Regimes and Firms' Financial Health}

Notes: PA, PI and OT denote pure assembly, processing with imports, and ordinary trade, respectively. The unit of observation is the firm in columns 1-4 and the firmdestination in columns 5-8. T-statistics based on robust standard errors reported in parenthesis in columns $1-4$ and clustered by firm in columns $5-8$. *** $* *$, and * indicate significance at the $1 \%, 5 \%$, and $10 \%$ level.

\begin{tabular}{|c|c|c|c|c|c|c|c|c|}
\hline \multirow[b]{2}{*}{ Dep Variable: } & \multicolumn{2}{|c|}{ Current Fin Health } & \multicolumn{6}{|c|}{ Lagged Fin Health } \\
\hline & $\frac{P A+P I}{P A+P I+O T}$ & $\frac{P A}{P A+P I}$ & $\frac{P A+P I}{P A+P I+O T}$ & $\frac{P A}{P A+P I}$ & $\frac{P A+P I}{P A+P I+O T}$ & $\frac{P A}{P A+P I}$ & $\frac{P A+P I}{P A+P I+O T}$ & $\frac{P A}{P A+P I}$ \\
\hline
\end{tabular}

(3)

(4)

(5)

(6)

(7)

(8)

Panel A. Liquidity = ( current assets - current liability $) /$ total assets

Liquidity

$-0.026^{\star \star *}-0.039$ *** $-0.025^{\star \star \star} \quad-0.024$

$(-5.36)$

$(-4.85)$

$(-5.09)$

$-0.024^{\star *}$
$(-3.15)$

$-0.028 * \star \star$

$-0.039 * \star \star$

$-0.013^{*}$

$-0.029 * *$

Productivity

R-squared

$0.44 \quad 0.24$

0.24
22,059

0.44

20,555

$(-3.88)$

$(-3.23)$

$(-1.66)$

$(-2.24)$

\# observations

50,490

46,573

0.43

$-0.016$

$(-5.99) \quad(-6.77)$

$0.43 \quad 0.22$

\section{Panel B. Leverage $=$ short-term debt $I$ current assets}

Leverage

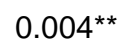

$0.022^{\star \star \star}$

$0.003^{\star \star \star}$

$0.007^{\text {** }}$

409,249

0.21

380,102

126,592

Productivity

(6.85)

(3.18)

(2.05)

$0.005^{\star \star \star}$

$0.013^{\star \star *}$

$0.004^{\star \star *}$

$0.013^{\star \star *}$

R-squared

$0.44 \quad 0.24$

0.44

0.23

$46,557 \quad 20,545$

0.43

409,120

135,054

(2.66)

(4.04)

$50,483 \quad 22,058$

$Y$
$Y$

Empl, Own FE

Prov FE, Ind FE

Country FE

$\begin{array}{ll}Y & Y \\ Y & Y \\ - & -\end{array}$

$Y$
$Y$
-

$Y$
$Y$
-

$Y$
$Y$
-

$Y$
$Y$
$Y$

$\mathrm{Y}$
$\mathrm{Y}$
$\mathrm{Y}$

$\begin{array}{ll}Y & Y \\ Y & Y \\ Y & Y\end{array}$


Table 5. Trade Regimes and Sectors' Financial Vulnerability

Notes: PA, PI and OT denote pure assembly, processing with imports, and ordinary trade, respectively. The unit of observation is the firm-sector in columns 1-2 and the firm-sector-destination in columns 3-4. All regressions control for sectors' physical capital $(\mathrm{K})$, human capital $(\mathrm{H})$ and relationship-specific (RS) intensity. T-statistics based on robust standard errors clustered by firm reported in parenthesis. ${ }^{* \star}$, **, and * indicate significance at the $1 \%, 5 \%$, and $10 \%$ level.

\begin{tabular}{|c|c|c|c|c|}
\hline Dep Variable: & $\begin{array}{c}P A+P I \\
P A+P I+O T \\
\text { (1) }\end{array}$ & $\begin{array}{c}P A \\
P A+P I \\
\text { (2) }\end{array}$ & $\begin{array}{c}P A+P I \\
P A+P I+O T \\
\text { (3) }\end{array}$ & $\begin{array}{c}P A \\
P A+P I \\
\text { (4) }\end{array}$ \\
\hline \multicolumn{5}{|c|}{ Panel A. Working Capital Requirements: Inventories Ratio } \\
\hline Inventories Ratio & $\begin{array}{l}0.497^{\star \star \star} \\
(23.43)\end{array}$ & $\begin{array}{l}0.201^{\star \star \star} \\
(2.77)\end{array}$ & $\begin{array}{l}0.538^{\star * \star} \\
(20.90)\end{array}$ & $\begin{array}{l}0.084^{\star *} \\
(1.99)\end{array}$ \\
\hline $\mathrm{K}$ intensity & $-0.310^{\star \star \star}$ & 0.151 & $-0.176^{\star \star \star}$ & 0.021 \\
\hline $\mathrm{H}$ intensity & $0.016^{\star \star \star}$ & -0.016 & $0.026^{\star \star \star}$ & -0.011 \\
\hline RS intensity & $0.017^{\star \star \star}$ & -0.002 & $0.024^{\star \star \star}$ & $0.024^{*}$ \\
\hline R-squared & 0.86 & 0.97 & 0.83 & 0.94 \\
\hline \multicolumn{5}{|c|}{ Panel B. Long-Run Investment Needs: External Finance Dependence } \\
\hline Ext Fin Dependence & $\begin{array}{l}0.050 * \star \star \\
(21.82)\end{array}$ & $\begin{array}{l}-0.0001 \\
(-0.03)\end{array}$ & $\begin{array}{l}0.049 * * \star \\
(18.23)\end{array}$ & $\begin{array}{l}-0.002 \\
(-0.46)\end{array}$ \\
\hline $\mathrm{K}$ intensity & $-0.744^{\star \star \star}$ & -0.052 & $-0.734^{\star \star \star}$ & -0.066 \\
\hline $\mathrm{H}$ intensity & $0.019 * \star \star$ & -0.002 & $0.031^{\star \star \star}$ & -0.004 \\
\hline RS intensity & 0.003 & -0.016 & -0.002 & 0.017 \\
\hline R-squared & 0.86 & 0.97 & 0.83 & 0.94 \\
\hline \multicolumn{5}{|c|}{ Panel C. Long-Run Investment Needs: R\&D Intensity } \\
\hline R\&D Intensity & $\begin{array}{l}0.988^{\star \star \star} \\
(22.81)\end{array}$ & $\begin{array}{l}-0.018 \\
(-0.24)\end{array}$ & $\begin{array}{c}0.901^{\star \star \star} \\
(16.68)\end{array}$ & $\begin{array}{l}-0.032 \\
(-0.55)\end{array}$ \\
\hline K intensity & $-0.601 * \star \star$ & -0.053 & $-0.611^{\star \star \star}$ & $-0.069 *$ \\
\hline $\mathrm{H}$ intensity & $-0.009 * *$ & -0.001 & 0.005 & -0.003 \\
\hline RS intensity & $-0.022^{\star \star *}$ & -0.015 & $-0.020^{* \star *}$ & 0.018 \\
\hline R-squared & 0.86 & 0.97 & 0.83 & 0.94 \\
\hline \multicolumn{5}{|c|}{ Panel D. Access to Collateral: Asset Tangibility } \\
\hline Asset Tangibility & $\begin{array}{l}-0.208^{\star \star \star} \\
(-18.05)\end{array}$ & $\begin{array}{l}-0.038 \\
(-1.12)\end{array}$ & $\begin{array}{l}-0.207^{\star \star *} \\
(-15.94)\end{array}$ & $\begin{array}{c}-0.028 \\
(-1.42)\end{array}$ \\
\hline K intensity & -0.036 & 0.083 & 0.026 & 0.029 \\
\hline $\mathrm{H}$ intensity & $0.012^{\star \star \star}$ & -0.008 & $0.025^{\star \star \star}$ & -0.009 \\
\hline RS intensity & $0.019 * \star \star$ & -0.011 & $0.023^{\star \star \star}$ & 0.021 \\
\hline R-squared & 0.86 & 0.97 & 0.83 & 0.94 \\
\hline Firm FE & Y & Y & Y & Y \\
\hline Country FE & - & - & $\mathrm{Y}$ & Y \\
\hline \# firms & 110,018 & 41,041 & 110,018 & 41,041 \\
\hline \# observations & 252,296 & 59,263 & $1,142,871$ & 264,585 \\
\hline
\end{tabular}


Table 6. Alternative Specification: Binary Trade Regime Shares

Notes: PA, PI and OT denote pure assembly, processing with imports, and ordinary trade, respectively. The unit of observation is the firm-destination in columns 1-4 and the firm-sector-destination in columns 5 -8. The outcome variable equals 1 for all values above 0 . T-statistics based on robust standard errors clustered by firm reported in parenthesis. ${ }^{* \star *},{ }^{* *}$, and ${ }^{*}$ indicate significance at the $1 \%, 5 \%$, and $10 \%$ level.

\begin{tabular}{|c|c|c|c|c|c|c|c|c|}
\hline \multirow[b]{2}{*}{ Dep Variable: } & \multicolumn{4}{|c|}{ Lagged Firm Fin Health } & \multicolumn{4}{|c|}{ Sectors' Fin Vulnerability } \\
\hline & $\begin{array}{c}P A+P I \\
P A+P I+O T \\
(1)\end{array}$ & $\begin{array}{c}P A \\
P A+P I \\
(2)\end{array}$ & $\begin{array}{c}P A+P I \\
P A+P I+O T \\
\text { (3) }\end{array}$ & $\begin{array}{c}P A \\
P A+P I \\
\text { (4) }\end{array}$ & $\frac{P A+P I}{P A+P I+O T}$ & $\begin{array}{c}P A \\
P A+P I \\
\text { (6) }\end{array}$ & $\begin{array}{c}P A+P I \\
P A+P I+O T \\
(7)\end{array}$ & $\begin{array}{c}P A \\
P A+P I \\
\text { (8) }\end{array}$ \\
\hline Liquidity & $\begin{array}{l}-0.029 * \star * \\
(-3.94)\end{array}$ & $\begin{array}{l}-0.037^{\star \star \star} \\
(-3.04)\end{array}$ & & & & & & \\
\hline Leverage & & & $\begin{array}{l}0.005^{\star \star \star} \\
(3.87)\end{array}$ & $\begin{array}{l}0.013^{\star \star \star} \\
(4.10)\end{array}$ & & & & \\
\hline Inventories Ratio & & & & & $\begin{array}{l}0.675^{\star \star \star} \\
(22.75)\end{array}$ & $\begin{array}{l}0.149 * \star * \\
(3.01)\end{array}$ & & \\
\hline Ext Fin Dependence & & & & & & & $\begin{array}{l}0.060 * * \star \\
(19.40)\end{array}$ & $\begin{array}{l}0.0004 \\
(0.08)\end{array}$ \\
\hline $\begin{array}{l}\text { R-squared } \\
\text { \# observations }\end{array}$ & $\begin{array}{l}0.39 \\
409,249\end{array}$ & $\begin{array}{l}0.23 \\
135,109\end{array}$ & $\begin{array}{l}0.39 \\
409,120\end{array}$ & $\begin{array}{l}0.23 \\
135,054\end{array}$ & $\begin{array}{l}0.77 \\
1,142,871\end{array}$ & $\begin{array}{l}0.92 \\
264,585\end{array}$ & $\begin{array}{l}0.77 \\
1,142,871\end{array}$ & $\begin{array}{l}0.92 \\
264,585\end{array}$ \\
\hline Country FE & $\mathrm{Y}$ & Y & $\mathrm{Y}$ & $\mathrm{Y}$ & Y & Y & Y & Y \\
\hline Empl, Own FE & $\mathrm{Y}$ & $\mathrm{Y}$ & $\mathrm{Y}$ & $\mathrm{Y}$ & - & - & - & - \\
\hline Prov FE, Ind FE & $\mathrm{Y}$ & $\mathrm{Y}$ & $\mathrm{Y}$ & $\mathrm{Y}$ & - & - & - & - \\
\hline Firm FE & - & - & - & - & $\mathrm{Y}$ & $\mathrm{Y}$ & Y & $\mathrm{Y}$ \\
\hline $\mathrm{K}, \mathrm{H}, \mathrm{RS}$ intensity & - & - & - & - & $\mathrm{Y}$ & $\mathrm{Y}$ & $\mathrm{Y}$ & $\mathrm{Y}$ \\
\hline
\end{tabular}




\section{Table 7. Variation in Financial Development across Chinese Regions}

Notes: PA, PI and OT denote pure assembly, processing with imports, and ordinary trade, respectively. The unit of observation is the firm-destination in columns 1-4 and the firm-sector-destination in columns 5-8. The outcome variable is continuous in columns 1-2 and 5-6, and equals 1 for all values above 0 in columns 3-4 and 7-8. High Fin Devt is a dummy set to 1 for Chinese regions with financial development above the median. T-statistics based on robust standard errors clustered by firm reported in parenthesis. $\star \star \star * *$, and * indicate significance at the $1 \%, 5 \%$, and $10 \%$ level.

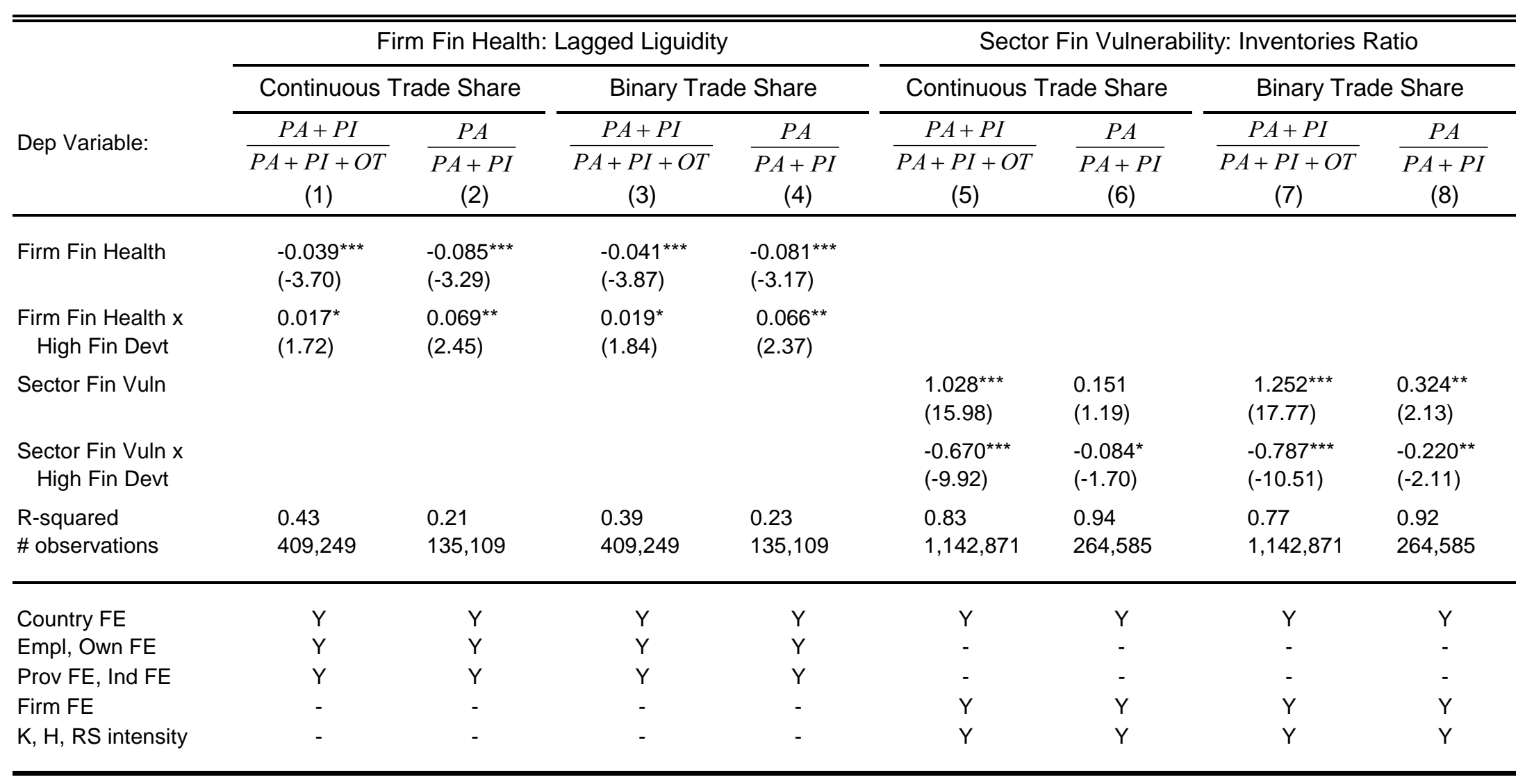




\section{Table 8. Variation in Financial Development across Export Destinations}

Notes: PA, PI and OT denote pure assembly, processing with imports, and ordinary trade, respectively. The unit of observation is the firm-destination in columns 1-4 and the firm-sector-destination in columns 5-8. The outcome variable is continuous in columns 1-2 and 5-6, and equals 1 for all values above 0 in columns 3-4 and 7-8. High Dest Fin Devt is a dummy set to 1 for export destinations with financial development above the median. T-statistics based on robust standard errors clustered by firm reported in parenthesis. ${ }^{* \star},{ }^{\star *}$, and * indicate significance at the $1 \%, 5 \%$, and $10 \%$ level.

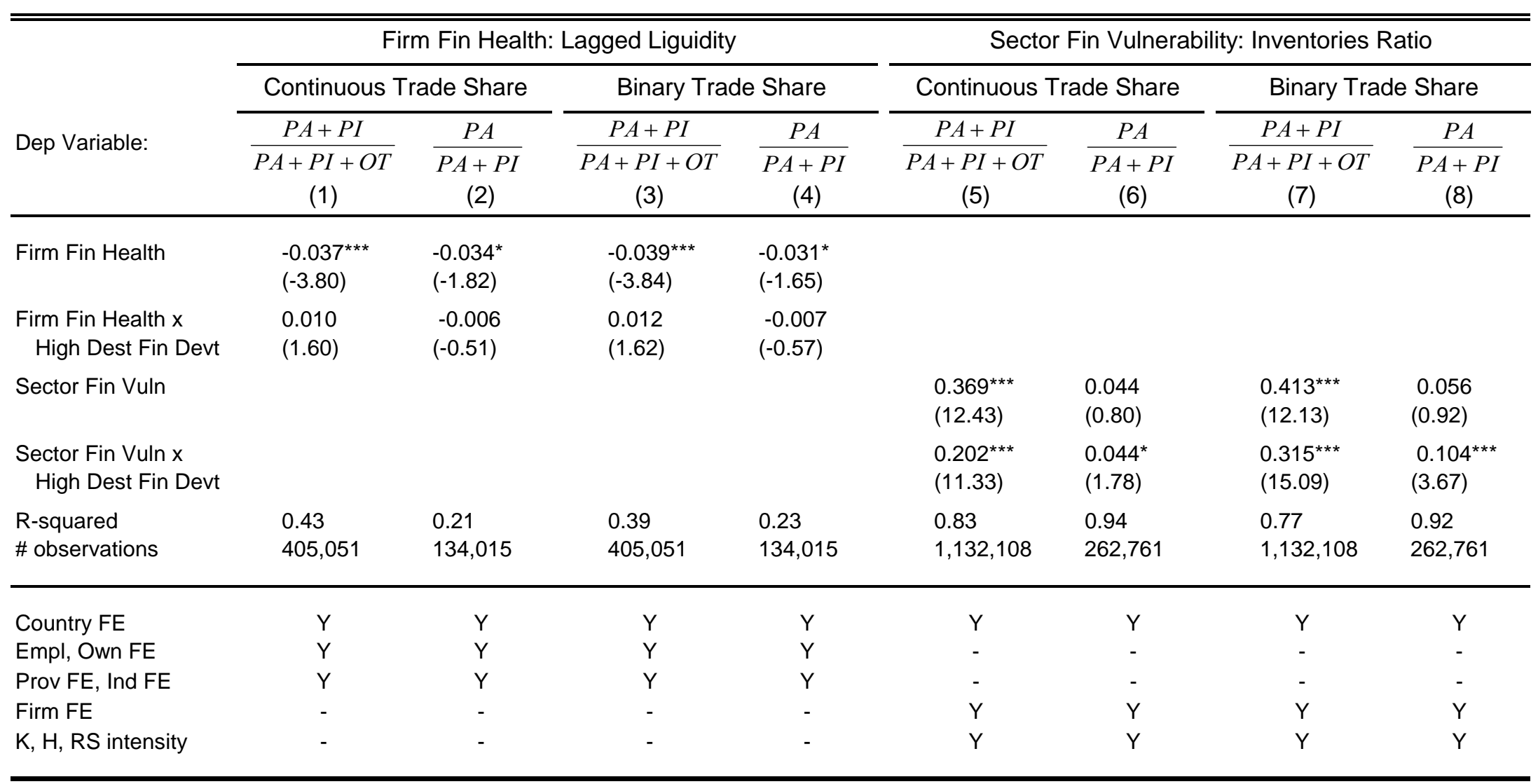


Table 9. Variation in Relationship Specificity across Sectors

Notes: PA, PI and OT denote pure assembly, processing with imports, and ordinary trade, respectively. The unit of observation is the firm-destination in columns 1-4 and the firm-sector-destination in columns 5-8. The outcome variable is continuous in columns 1-2 and 5-6, and equals 1 for all values above 0 in columns 3-4 and 7-8. High RS intensity is a dummy set to 1 for sectors with relationship specificity above the median. T-statistics based on robust standard errors clustered by firm reported in parenthesis. $* * *, * *$, and * indicate significance at the $1 \%, 5 \%$, and $10 \%$ level.

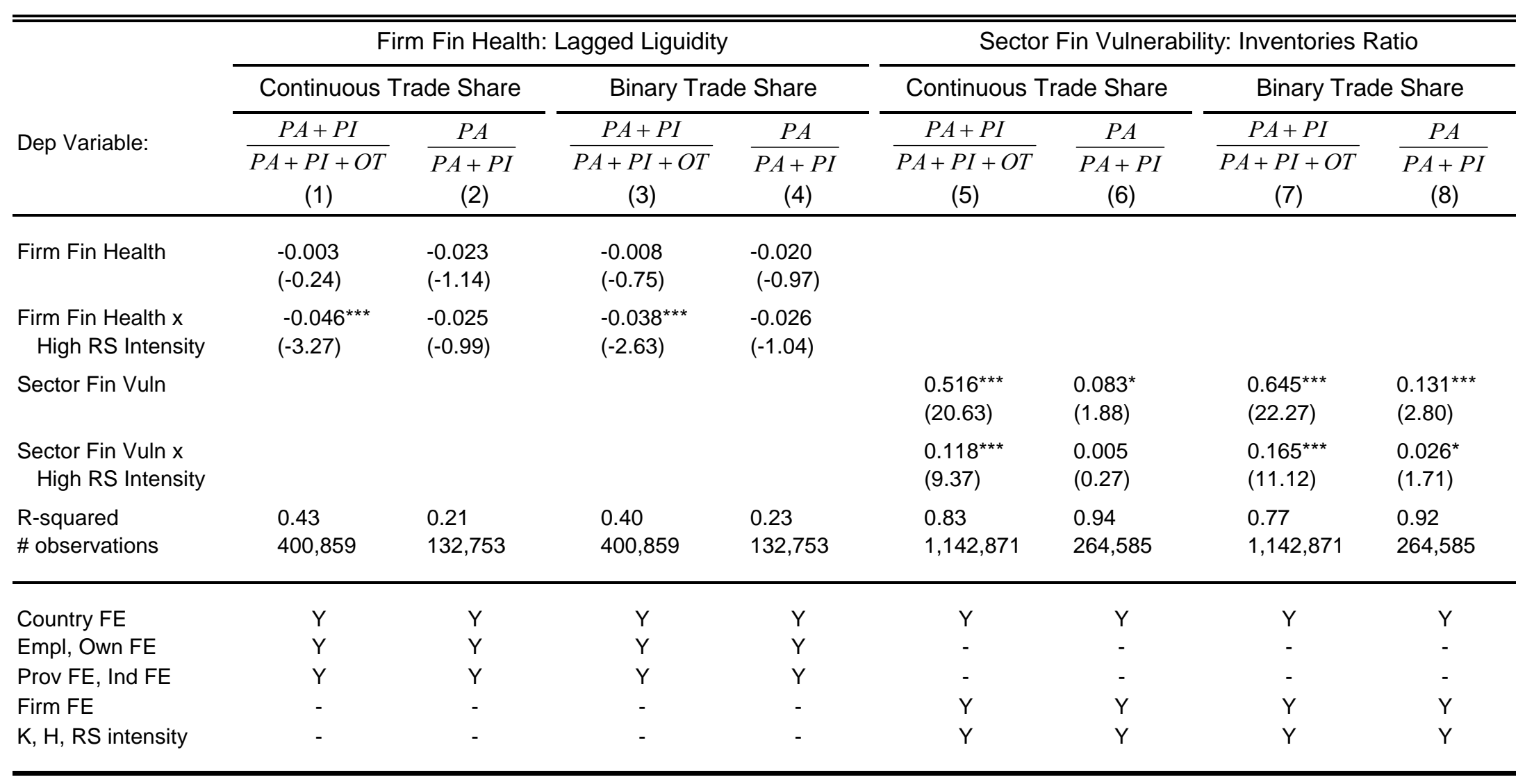




\section{Table 10. Import Trade Regimes and Firms' Financial Health}

Notes: PA, PI and OT denote export flows under pure assembly, processing with imports, and ordinary trade, respectively. IPA, IPI and IOT denote import flows under pure assembly, processing with imports, and ordinary trade, respectively. T-statistics based on robust standard errors reported in parenthesis. ***, **, and * indicate significance at the $1 \%, 5 \%$, and $10 \%$ level.

\begin{tabular}{|c|c|c|c|c|c|}
\hline & (1) & (2) & (3) & (4) & (5) \\
\hline \multicolumn{6}{|c|}{ Panel A. Dep. Variable: (IPA + IPI) / (IPA + IPI + IOT) } \\
\hline$(\mathrm{PA}+\mathrm{PI}) /(\mathrm{PA}+\mathrm{PI}+\mathrm{OT})$ & $\begin{array}{l}0.603^{\star \star \star} \\
(111.97)\end{array}$ & & & & \\
\hline Liquidity & & $\begin{array}{l}-0.026^{\star \star \star} \\
(-4.51)\end{array}$ & $\begin{array}{l}-0.014^{\star \star} \\
(-2.33)\end{array}$ & & \\
\hline Leverage & & & & $\begin{array}{l}0.002^{\star} \\
(1.95)\end{array}$ & $\begin{array}{l}0.001 \\
(0.92)\end{array}$ \\
\hline Productivity & & & $\begin{array}{l}-0.028^{\star \star *} \\
(-12.00)\end{array}$ & & $\begin{array}{l}-0.029 * \star \star \\
(-12.54)\end{array}$ \\
\hline $\begin{array}{l}\text { R-squared } \\
\text { \# observations }\end{array}$ & $\begin{array}{l}0.58 \\
30,274\end{array}$ & $\begin{array}{l}0.40 \\
32,530\end{array}$ & $\begin{array}{l}0.40 \\
30,167\end{array}$ & $\begin{array}{l}0.40 \\
32,518\end{array}$ & $\begin{array}{l}0.40 \\
30,159\end{array}$ \\
\hline \multicolumn{6}{|c|}{ Panel B. Dep. Variable: IPA / (IPA + IPI) } \\
\hline $\mathrm{PA} /(\mathrm{PA}+\mathrm{PI})$ & $\begin{array}{l}0.946 \star \star \star \star \\
(294.23)\end{array}$ & & & & \\
\hline Liquidity & & $\begin{array}{l}-0.021^{\star \star \star} \\
(-2.86)\end{array}$ & $\begin{array}{l}-0.015^{\star} \\
(-1.94)\end{array}$ & & \\
\hline Leverage & & & & $\begin{array}{l}0.007^{\star *} \\
(2.02)\end{array}$ & $\begin{array}{l}0.007^{*} \\
(1.86)\end{array}$ \\
\hline Productivity & & & $\begin{array}{l}-0.017^{\star \star \star} \\
(-6.33)\end{array}$ & & $\begin{array}{l}-0.016^{\star \star \star} \\
(-6.12)\end{array}$ \\
\hline $\begin{array}{l}\text { R-squared } \\
\text { \# observations }\end{array}$ & $\begin{array}{l}0.93 \\
20,483\end{array}$ & $\begin{array}{l}0.21 \\
20,952\end{array}$ & $\begin{array}{l}0.21 \\
19,505\end{array}$ & $\begin{array}{l}0.21 \\
20,944\end{array}$ & $\begin{array}{l}0.22 \\
19,500\end{array}$ \\
\hline Ownership FE & $\mathrm{Y}$ & $\mathrm{Y}$ & Y & $\mathrm{Y}$ & $\mathrm{Y}$ \\
\hline Province FE, Industry FE & $\mathrm{Y}$ & $\mathrm{Y}$ & $\mathrm{Y}$ & $\mathrm{Y}$ & $\mathrm{Y}$ \\
\hline Employment & $\mathrm{N}$ & $\mathrm{Y}$ & $\mathrm{Y}$ & $\mathrm{Y}$ & $\mathrm{Y}$ \\
\hline
\end{tabular}




\section{Figure 1. The Distribution of Firms Across Trade Regimes}

This figure summarizes the composition of firms' trade activity in 2005. Each segment gives the percentage share of firms active in a given set of export trade regimes. Firms in the red circle are engaged in ordinary trade (OT); in the blue circle - in pure assembly (PA); and in the yellow circle - in import and assembly (PI). Firms in overlapping segments of the three circles export under multiple trade regimes. The percentages reported sum to $100 \%$.

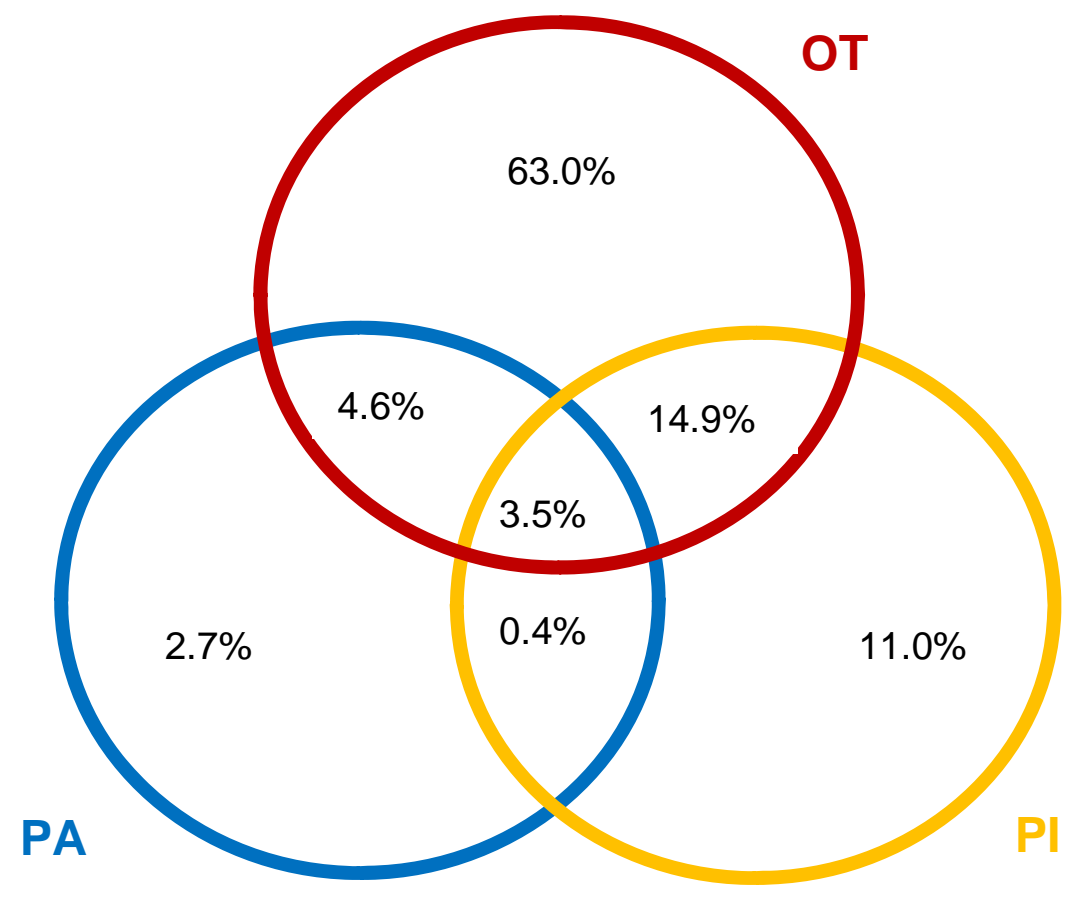

Figure 2. The Distribution of Export Value Across Trade Regimes

This figure replicates Figure 1, but instead of showing the percentage share of firms in a segment, it reports the percentage share of total exports captured by firms in that segment.

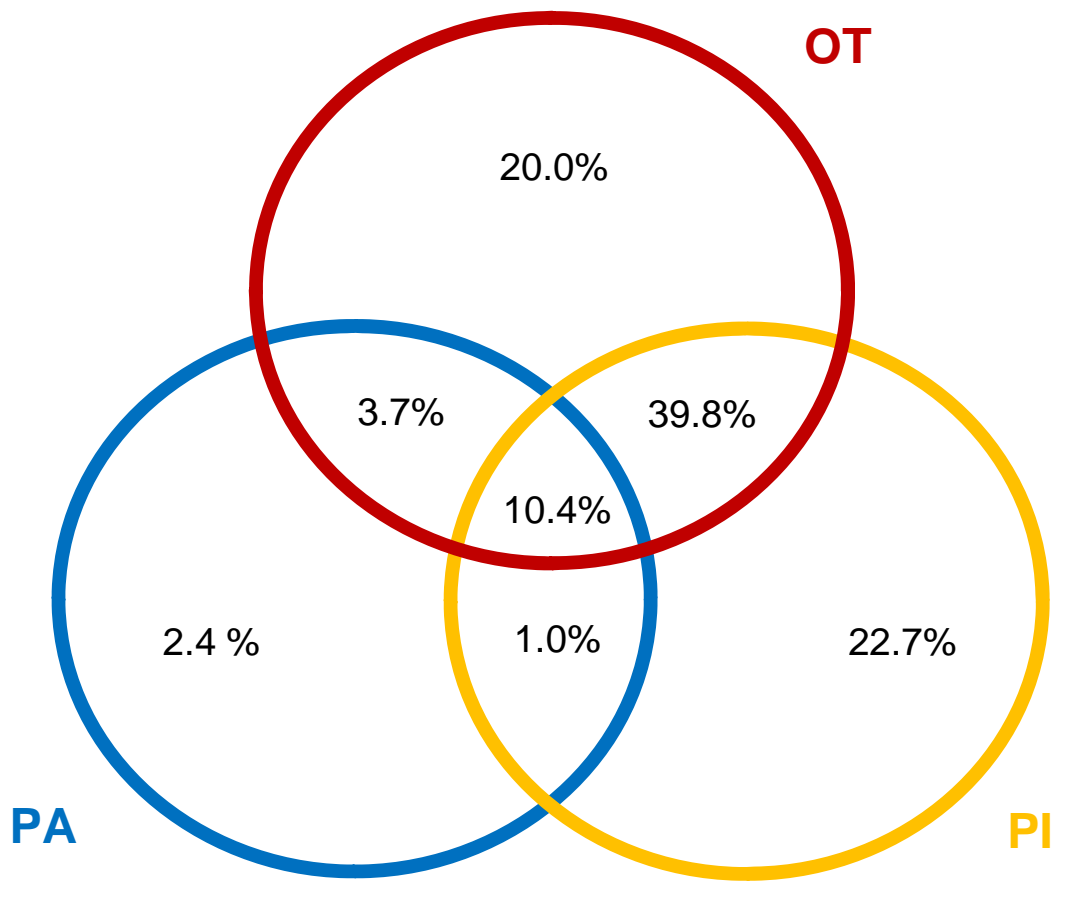


Figure 3. Input Sourcing Strategies Across Firms

This figure summarizes the use of imported inputs by firms reporting ordinary exports (left bar) and firms reporting processing exports (right bar) in 2005. Each segment gives the percentage share of firms using no imported inputs (grey), inputs imported under processing trade (yellow), inputs imported under ordinary trade (blue), and inputs imported under both regimes (red). The percentages reported in each bar sum to $100 \%$.

Figure 3A. Firms reporting both ordinary and processing exports enter both bars

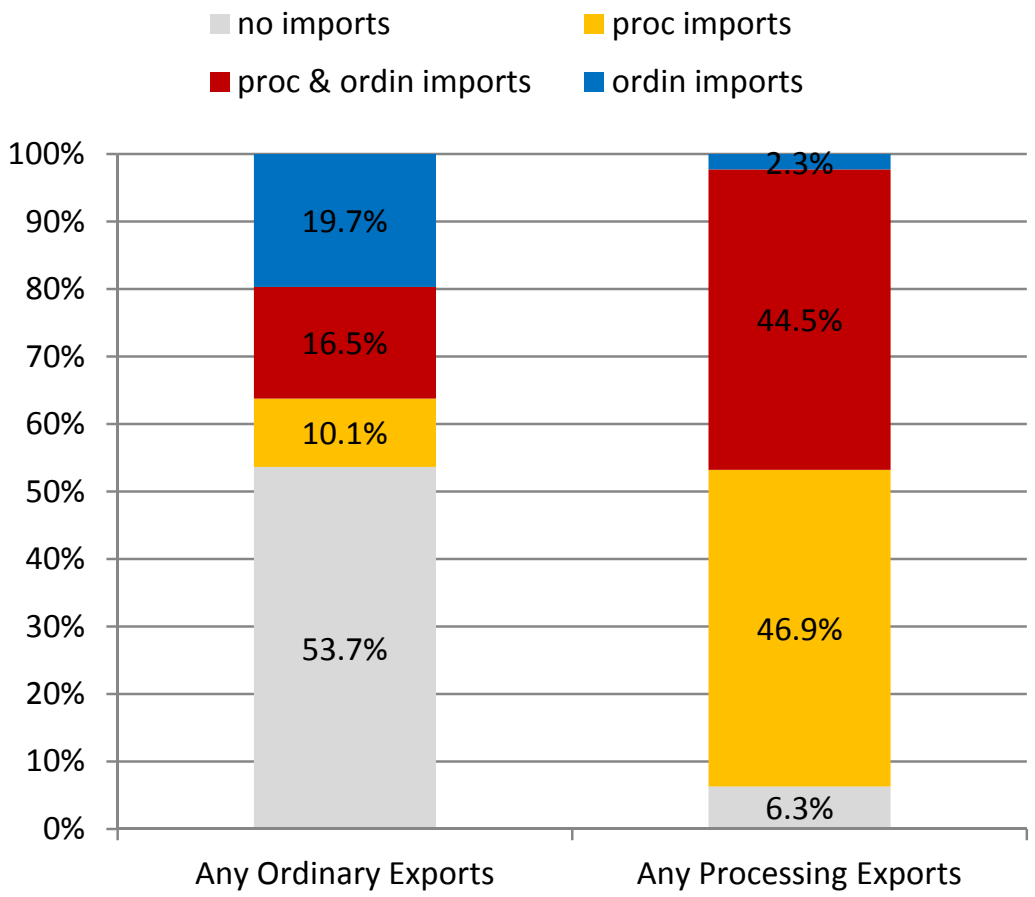

Figure 3B. Firms reporting both ordinary and processing exports are excluded

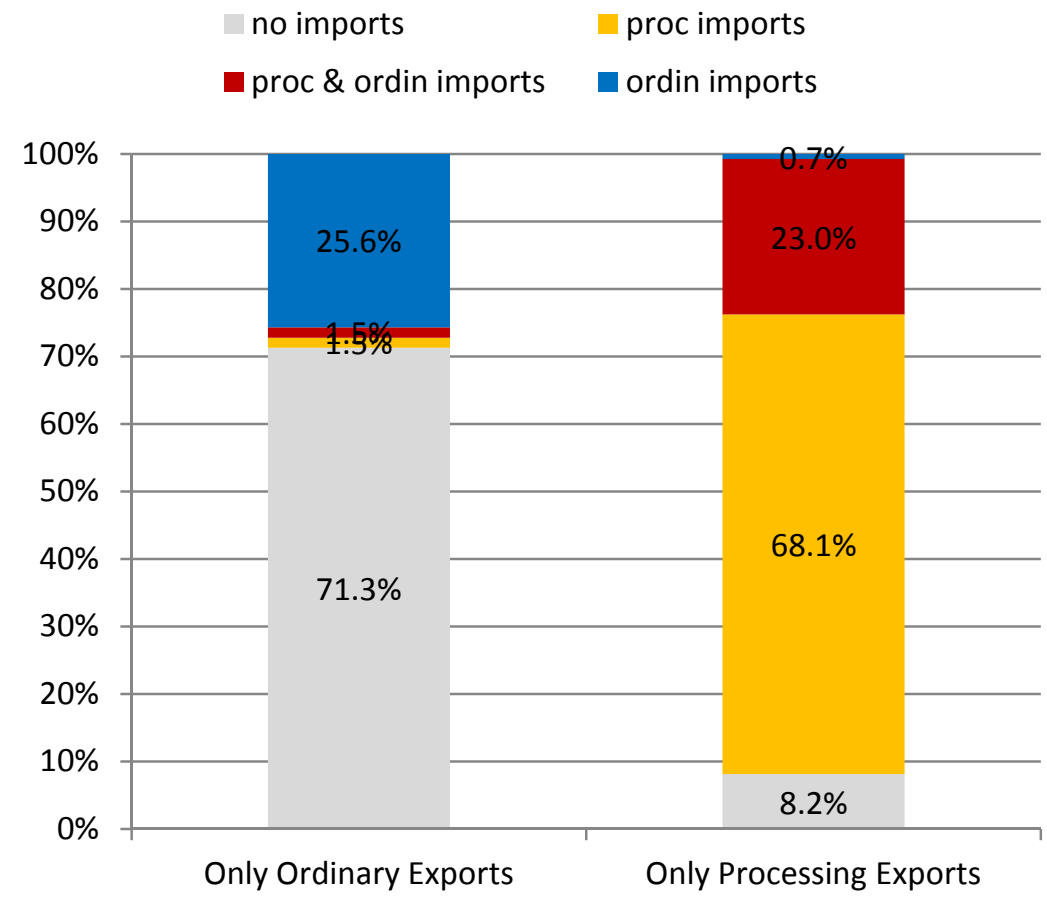


Figure 4. Trade Shares Across Firms and Sectors

This figure shows how the propensity for firms to pursue different trade regimes varies with firms' financial health (Figure 4A) and with sectors' working capital requirements (Figure 4B) in 2005. In Figure 4A, firms are split into two subsamples with liquidity above or below the sample median. In Figure 4B, sectors are split into sectors with inventory ratios above and below the median. The left bars (red) report the average share of processing trade in total exports, $(\mathrm{PA}+\mathrm{PI}) /(\mathrm{PA}+\mathrm{PI}+\mathrm{OT})$, across firms in a sample. The right bars (yellow) report the average share of pure assembly in processing trade, $\mathrm{PA} /(\mathrm{PA}+\mathrm{PI})$, across firms in a sample.

Figure 4A. Firms' financial health

$$
\square(\mathrm{PA}+\mathrm{PI}) /(\mathrm{PA}+\mathrm{PI}+\mathrm{OT}) \quad \square \mathrm{PA} /(\mathrm{PA}+\mathrm{PI})
$$

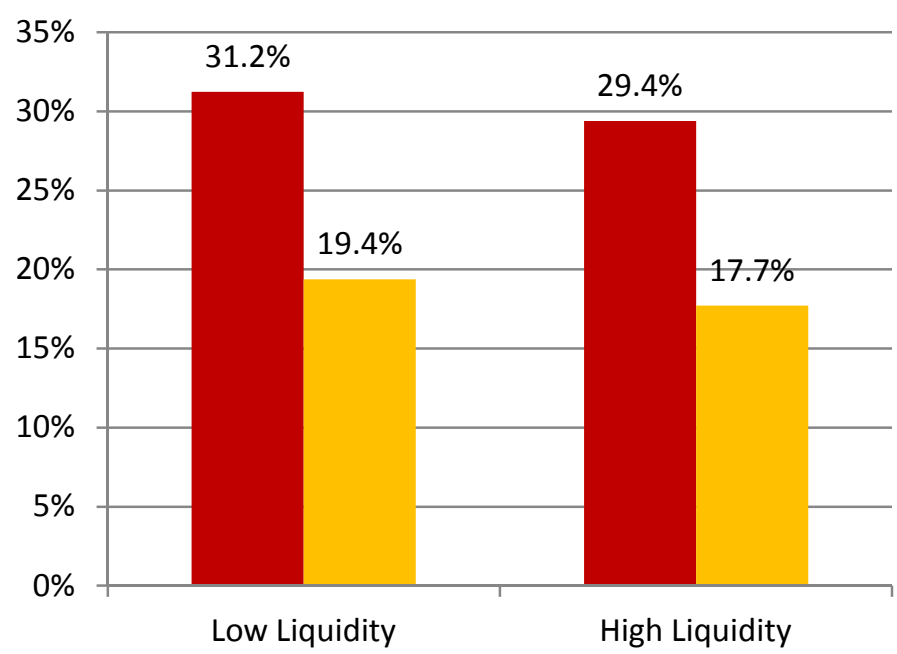

Figure 4B. Sectors' working capital requirement

$$
\square(\mathrm{PA}+\mathrm{PI}) /(\mathrm{PA}+\mathrm{PI}+\mathrm{OT}) \quad \square \mathrm{PA} /(\mathrm{PA}+\mathrm{PI})
$$

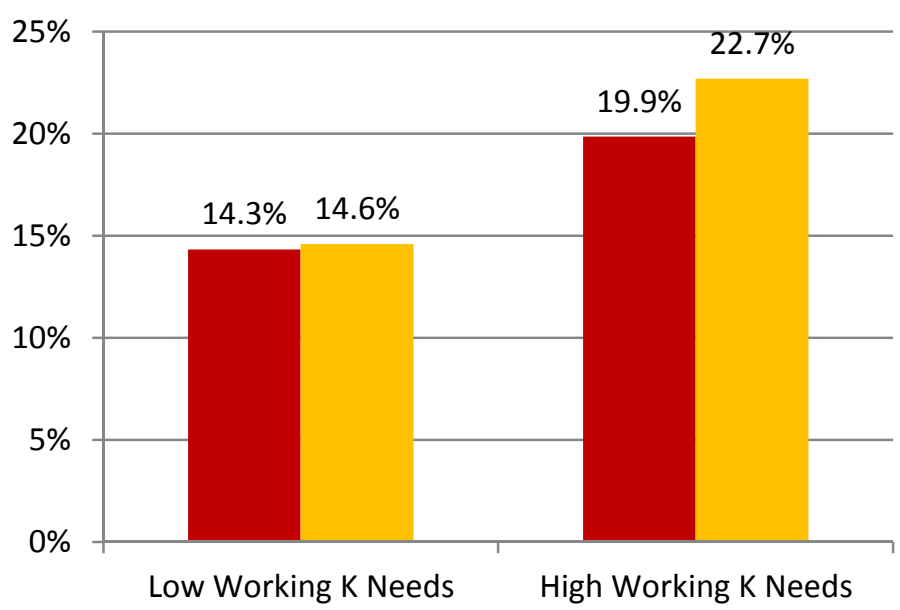




\section{Appendix Table 1. Total Exports, Domestic Sales and Processing Imports}

Notes: PA, PI and OT denote pure assembly, processing with imports, and ordinary trade, respectively. T-statistics based on robust standard errors reported in parenthesis. ${ }^{* * *},{ }^{* *}$, and * indicate significance at the $1 \%, 5 \%$, and $10 \%$ level.

\begin{tabular}{lccc}
\hline \hline Dep Variable: & $(\log )$ Dom Sales & $(\log )$ Exports & $(\log )$ Proc Imports \\
& $(1)$ & $(2)$ & $(3)$ \\
\hline
\end{tabular}

Panel A. Processing Trade vs. Ordinary Trade

$\begin{array}{llll}\text { ( PA + PI ) / ( PA + PI + OT ) } & -1.850^{\star \star \star} & 0.960^{\star \star \star} & 3.073^{\star \star \star} \\ & (-34.52) & (38.61) & (80.01) \\ \text { (log) Employment } & 0.701^{\star \star \star} & 0.743^{\star \star \star} & 0.802^{\star \star \star} \\ & (42.81) & (90.90) & (73.88) \\ \text { R-squared } & 0.33 & 0.31 & 0.53 \\ \text { \# observations } & 50,507 & 50,522 & 21,611\end{array}$

Panel B. Pure Assembly vs. Import \& Assembly

$\begin{array}{llll}\text { PA / ( PA + PI ) } & -0.149^{\star} & -0.259^{\star \star \star} & 0.072^{\star} \\ & (-1.75) & (-8.59) & (1.77) \\ \text { (log) Employment } & 0.514^{\star \star \star} & 0.918^{\star \star \star} & 0.857^{\star \star \star} \\ & (18.47) & (92.73) & (69.53) \\ \text { R-squared } & 0.29 & 0.43 & 0.36 \\ \text { \# observations } & 22,064 & 22,071 & 20,483\end{array}$

Ownership FE

Province FE, Industry FE

\begin{tabular}{lll}
$Y$ & $Y$ & $Y$ \\
$Y$ & $Y$ & $Y$ \\
\hline
\end{tabular}

